U.S. Department of the Interior

U.S. Geological Survey

\title{
Anthropogenic Constituents in Shallow Ground Water in the Upper Illinois River Basin
}

\author{
By William S. Morrow
}

Water-Resources Investigations Report 02-4293 


\section{U.S. DEPARTMENT OF THE INTERIOR \\ GALE A. NORTON, Secretary}

U.S. GEOLOGICAL SURVEY

Charles G. Groat, Director

The use of firm, trade, and brand names in this report is for identification purposes only and does not constitute endorsement by the U.S. Government.

For additional information write to:

Copies of this report can be purchased from:

District Chief

U.S. Geological Survey

221 N. Broadway Avenue

Urbana, IL 61801
U.S. Geological Survey

Branch of Information Services

Box 25286

Denver, CO 80225-0286 


\section{FOREWORD}

The U.S. Geological Survey (USGS) is committed to serve the Nation with accurate and timely scientific information that helps enhance and protect the overall quality of life, and facilitates effective management of water, biological, energy, and mineral resources. Information on the quality of the Nation's water resources is of critical interest to the USGS because it is so integrally linked to the long-term availability of water that is clean and safe for drinking and recreation and that is suitable for industry, irrigation, and habitat for fish and wildlife. Escalating population growth and increasing demands for the multiple water uses make water availability, now measured in terms of quantity and quality, even more critical to the long-term sustainability of our communities and ecosystems.

The USGS implemented the National WaterQuality Assessment (NAWQA) Program to support national, regional, and local information needs and decisions related to water-quality management and policy. Shaped by and coordinated with ongoing efforts of other Federal, State, and local agencies, the NAWQA Program is designed to answer: What is the condition of our Nation's streams and ground water? How are the conditions changing over time? How do natural features and human activities affect the quality of streams and ground water, and where are those effects most pronounced? By combining information on water chemistry, physical characteristics, stream habitat, and aquatic life, the NAWQA Program aims to provide science-based insights for current and emerging water issues. NAWQA results can contribute to informed decisions that result in practical and effective water-resource management and strategies that protect and restore water quality.

Since 1991, the NAWQA Program has implemented interdisciplinary assessments in more than 50 of the Nation's most important river basins and aquifers, referred to as Study Units. Collectively, these Study Units account for more than 60 percent of the overall water use and population served by public water supply, and are representative of the Nation's major hydrologic landscapes, priority ecological resources, and agricultural, urban, and natural sources of contamination.
Each assessment is guided by a nationally consistent study design and methods of sampling and analysis. The assessments thereby build local knowledge about water-quality issues and trends in a particular stream or aquifer while providing an understanding of how and why water quality varies regionally and nationally. The consistent, multi-scale approach helps to determine if certain types of waterquality issues are isolated or pervasive, and allows direct comparisons of how human activities and natural processes affect water quality and ecological health in the Nation's diverse geographic and environmental settings. Comprehensive assessments on pesticides, nutrients, volatile organic compounds, trace metals, and aquatic ecology are developed at the national scale through comparative analysis of the Study-Unit findings.

The USGS places high value on the communication and dissemination of credible, timely, and relevant science so that the most recent and available knowledge about water resources can be applied in management and policy decisions. We hope this NAWQA publication will provide you the needed insights and information to meet your needs, and thereby foster increased awareness and involvement in the protection and restoration of our Nation's waters.

The NAWQA Program recognizes that a national assessment by a single program cannot address all water-resource issues of interest. External coordination at all levels is critical for a fully integrated understanding of watersheds and for costeffective management, regulation, and conservation of our Nation's water resources. The Program, therefore, depends extensively on the advice, cooperation, and information from other Federal, State, interstate, Tribal, and local agencies, nongovernment organizations, industry, academia, and other stakeholder groups. The assistance and suggestions of all are greatly appreciated.

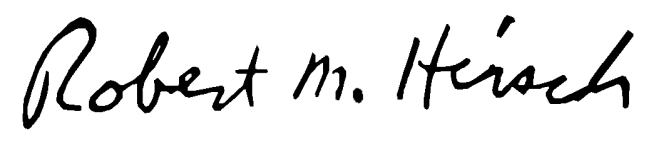

Robert M. Hirsch Associate Director for Water 



\section{CONTENTS}

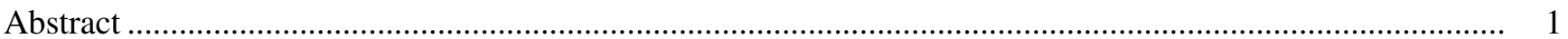

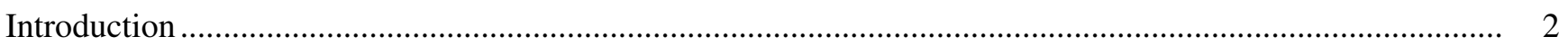

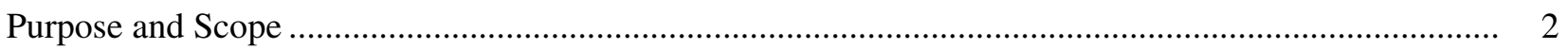

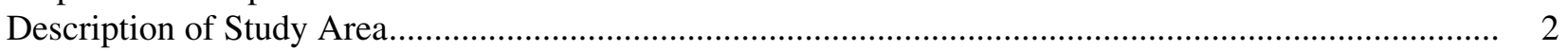

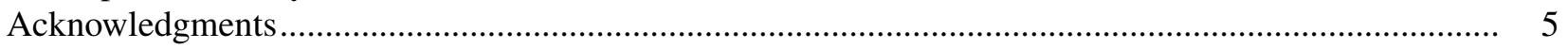

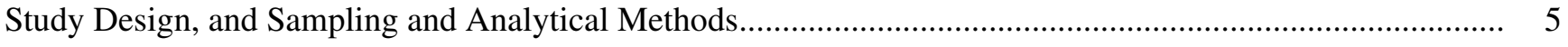

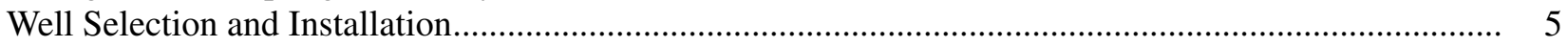

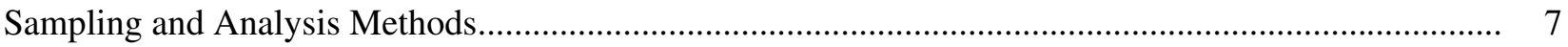

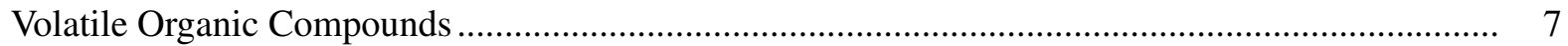

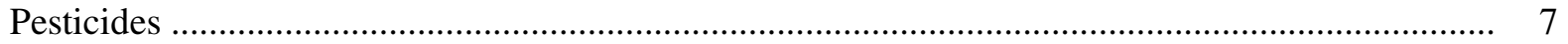

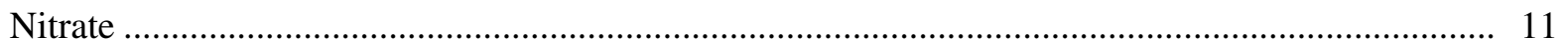

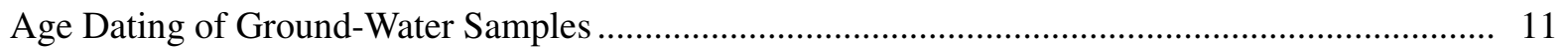

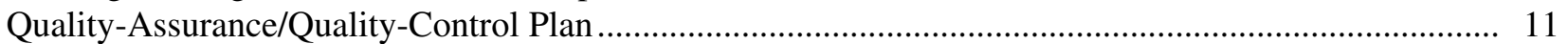

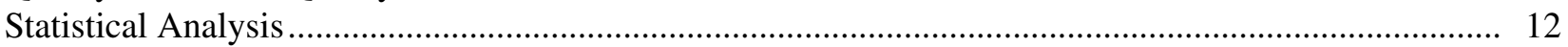

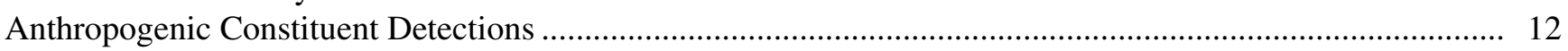

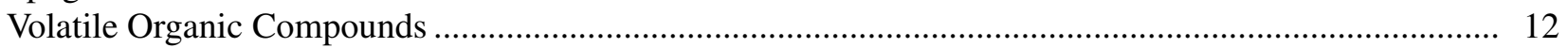

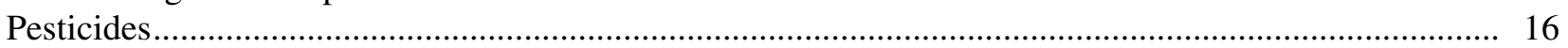

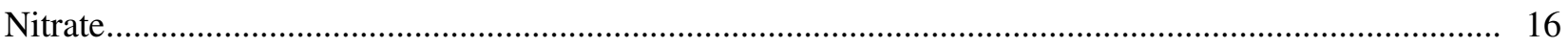

Relations among Anthropogenic Constituents with Other Chemical

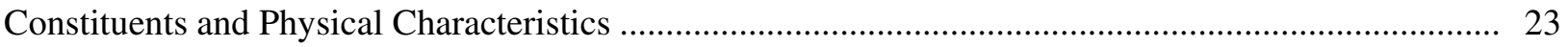

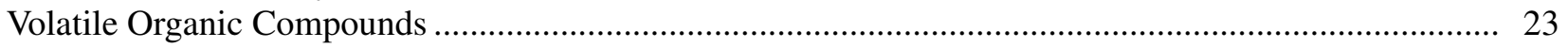

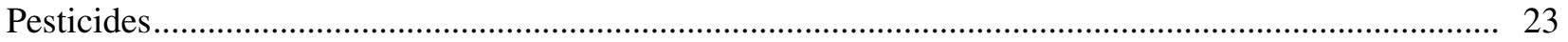

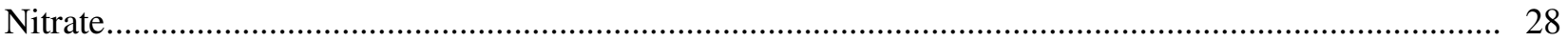

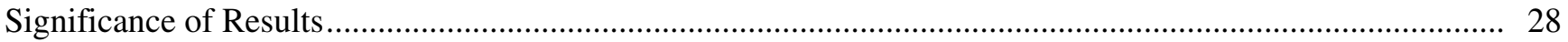

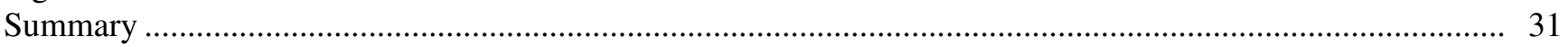

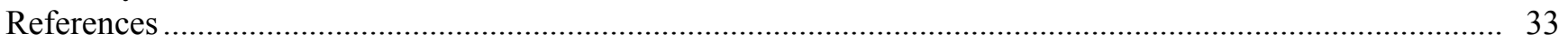

\section{FIGURES}

1-6. Maps showing:

1. Location of the upper Illinois River Basin............................................................................... 3

2. Physiography of the upper Illinois River Basin .............................................................................. 4

3. Urban land-use study area and well locations in urbanized areas in northern

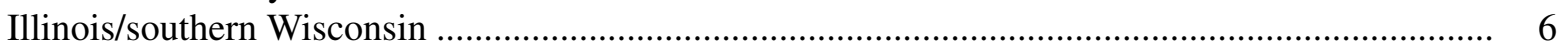

4. Volatile organic compound detections in wells in urbanized areas in northern Illinois/southern Wisconsin ............................................................................................... 15

5. Pesticide and pesticide transformation product detections in wells in urbanized

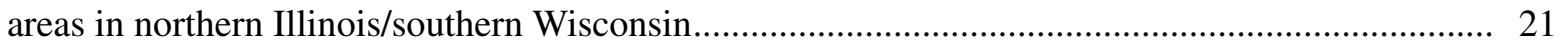

6. Nitrate detections in wells in urbanized areas in northern Illinois/southern Wisconsin....................... 22 
7-12. Graphs showing:

7. Concentration of chloroform as a function of (A) dissolved oxygen, (B) iron,

(C) nitrate concentrations, and as a function of (D) well depth in ground water

from urbanized areas in northern Illinois/southern Wisconsin, with Spearman

Rank Correlation

8. Concentration of total pesticides as a function of (A) the concentration of dissolved

oxygen, (B) ground-water apparent recharge date, and (C) well depth, and

concentration of total pesticides (with outlier removed) as a function of

(D) ground-water apparent recharge date in ground water from urbanized areas in northern Illinois/southern Wisconsin, with Spearman Rank Correlation

9. Concentration of the pesticides and pesticide transformation products (A) atrazine,

(B) deethylatrazine, (C) deethyldeisopropylatrazine, (D) deisopropylatrazine,

(E) hydroxyatrazine, (F) metolachlor ethane sulfonic acid (ESA), and

(G) prometon as a function of concentration of dissolved oxygen in ground

water from urbanized areas in northern Illinois/southern Wisconsin, with

Spearman Rank Correlation .....

10. Concentration of the pesticides and pesticide transformation products (A) atrazine,

(B) deethylatrazine, (C) deethyldeisopropylatrazine, (D) deisopropylatrazine,

(E) hydroxyatrazine, (F) metolachlor ethane sulfonic acid (ESA), and

(G) prometon as a function of well depth in ground water from urbanized

areas in northern Illinois/southern Wisconsin, with Spearman Rank Correlation

11. Concentration of the pesticides and pesticide transformation products (A) atrazine,

(B) deethylatrazine, (C) deethyldeisopropylatrazine, (D) deisopropylatrazine,

(E) hydroxyatrazine, $(\mathrm{F})$ metolachlor ethane sulfonic acid (ESA), and

(G) prometon as a function of ground-water apparent recharge date in ground

water from urbanized areas in northern Illinois/southern Wisconsin, with

Spearman Rank Correlation

12. Concentration of nitrate as a function of (A) arsenic, (B) dissolved oxygen

concentrations, (C) ground-water apparent recharge date, (D) iron concentration,

(E) nitrogen as ammonia concentration, and $(F)$ well depth in ground water from

urbanized areas in northern Illinois/southern Wisconsin, with Spearman Rank

Correlation

\section{TABLES}

1. Well dimensions for sampled wells in the upper Illinois River Basin

2. List of pesticides, pesticide transformation products, and volatile organic compounds with associated laboratory reporting level (LRL) ranges for 1999-2001

3. List of volatile organic compound detections at or above laboratory reporting levels

(LRLs) in 38 wells sampled in the upper Illinois River Basin, 2000-2001

4. List of volatile organic compound detections at or above information-rich method levels in 38 wells sampled in the upper Illinois River Basin

5. List of pesticide and pesticide transformation product detections at or above laboratory reporting levels (LRLs) in 42 wells sampled in the upper Illinois River Basin

6. List of pesticide and pesticide transformation product detections at or above information-rich method levels in 42 wells sampled in the upper Illinois River Basin 
CONVERSION FACTORS, ABBREVIATED WATER-QUALITY UNITS, AND OTHER ABBREVIATIONS

\begin{tabular}{rcl}
\hline Multiply & By & To obtain \\
\hline & Length & \\
inch (in.) & 25.4 & millimeter \\
foot (ft) & 0.3048 & meter \\
mile (mi) & 1.609 & kilometer \\
& Area & \\
square mile & 2.59 & square kilometer \\
& Radioactivity & \\
picocurie per liter $(\mathrm{pCi} / \mathrm{L})$ & 0.037 & becquerel per liter \\
\hline
\end{tabular}

\section{ABBREVIATED WATER-QUALITY UNITS}

Concentrations of chemical constituents in water are given either in milligrams per liter $(\mathrm{mg} / \mathrm{L})$ or micrograms per liter $(\mu \mathrm{g} / \mathrm{L})$.

\section{ABBREVIATIONS}

$\% \quad$ percent

TU tritium unit 


\title{
Anthropogenic Constituents in Shallow Ground Water in the Upper Illinois River Basin
}

\author{
By William S. Morrow
}

\section{Abstract}

The potential for anthropogenic effects on ground water is becoming of increasing concern as land throughout the Nation becomes more urbanized. The possible contamination of water resources by volatile organic compounds (VOCs), pesticides (including transformation products), and nitrate, from current urban land use and past agricultural land use, is of particular concern. As part of the U.S. Geological Survey's National Water-Quality Assessment program, water samples for analysis of VOCs, pesticides, and nitrate were collected from 43 wells in shallow (175 feet deep or less) ground water in glacial deposits overlying a major bedrock aquifer in recently urbanized areas in the Chicago, Ill. and Milwaukee, Wis. metropolitan counties.

Constituents were reported using two reporting levels. For the laboratory reporting level, the risk of a false positive or false negative detection is less than or equal to 1 percent. For the information-rich method level, estimated concentrations are identified positively and are qualified to be present on the basis of qualitycontrol criteria, but have a higher risk of false positive detections.

VOCs were detected in 32 percent (12 of 38) of the well samples with 15 detections of 7 VOCs, based on laboratory reporting levels. Concentrations ranged from 0.03 (estimated) to 4.6 micrograms per liter $(\mu \mathrm{g} / \mathrm{L})$, with a median concentration of $0.13 \mu \mathrm{g} / \mathrm{L}$. Methyl tert-butyl ether (MTBE) and trichloromethane (chloroform) were the most common with detections in 10 percent $(4$ of 38) of the well samples. Using information-rich method reporting levels, VOCs were detected in 74 percent of the wells with 37 detections of 15 VOCs. Chloroform was most common with detections in 24 percent ( 9 of 38) of the well samples.

Pesticides were detected in 62 percent ( 26 of 42) of the well samples with 83 detections of 20 pesticides, based on laboratory reporting levels for the respective constituent. Concentrations ranged from 0.003 (estimated) to 3.6 (estimated) $\mu \mathrm{g} / \mathrm{L}$, with a median concentration of $0.06 \mu \mathrm{g} / \mathrm{L}$. Deethylatrazine was most common with detections in 43 percent (18 of 42) of the well samples. Using information-rich method reporting levels, pesticides were detected in 74 percent (31 of 42) of the well samples with 134 detections of 29 pesticides. Deethylatrazine was most common with detections in 45 percent (19 of 42) of the well samples.

Nitrate concentrations ranged from less than 0.047 to 12.5 milligrams per liter $(\mathrm{mg} / \mathrm{L})$ with a median concentration of $0.068 \mathrm{mg} / \mathrm{L}$. Nitrate concentrations were greater than $2 \mathrm{mg} / \mathrm{L}$ in 30 percent (13 of 43) of the wells sampled.

Total VOC detections did not correlate well (less than Spearman Rank correlation value of plus or minus 0.10 ) with well depth, age, or dissolved oxygen. Total pesticide detections did correlate with dissolved oxygen and negatively correlated with well depth. Nitrate concentrations correlated with dissolved oxygen and apparent recharge date.

No VOC or pesticide concentrations exceeded U.S. Environmental Protection Agency drinking-water standards and only one nitrate 
detection exceeded the standards. However, of the 43 wells sampled for VOCs or pesticides using information-rich methods, or nitrate at laboratory reporting levels, 40 of 43 (93 percent) well samples had at least one detection of a VOC or pesticide, or a detection of nitrate above $2.0 \mathrm{mg} / \mathrm{L}$. This result indicates that most of these wells are anthropogenically affected, but presently not at U.S. Environmental Protection Agency drinkingwater regulation levels of concern. The wells sampled were not public drinking-water supplies; therefore, these wells were not subject to U.S. Environmental Protection Agency drinking-water regulations.

\section{INTRODUCTION}

In 1991, the U.S. Geological Survey (USGS) implemented the full-scale National Water-Quality Assessment (NAWQA) program to assess the quality of the ground- and surface-water resources of the United States, characterize the trends in the quality of these resources, and identify natural and anthropogenic (caused by humans) factors that affect water quality. The upper Illinois River Basin is one of more than 40 study units throughout the United States, where waterquality data are being collected as part of the NAWQA program.

The study area described here consists of selected rapidly expanding urban areas in and around Chicago, Ill. and Milwaukee, Wis. Urbanization of these once agricultural areas has affected ground-water quality (Kelly and Wilson, 2002). Anthropogenic effects on ground-water quality need to be evaluated in the basin because the shallow (less than $175 \mathrm{ft}$ deep) ground-water resources are used as a drinking-water supply. Characterizing the extent and nature of anthropogenic effects, such as increased contamination, may be used in planning for the wise use of these resources.

\section{Purpose and Scope}

This report presents the results of sampling and analysis of ground water in the upper Illinois River Basin during 2000-01 for concentrations of volatile organic compounds (VOCs), pesticides, and nitrate. These constituents in ground water are anthropogenic indicators of effects on water chemistry. For the purposes of this report, the term "pesticide" will include both the pesticide and pesticide transformation products. Water samples were collected from 43 randomly selected wells completed in glacial deposits in the upper Illinois River Basin.

\section{Description of the Study Area}

The upper Illinois River Basin covers an area of approximately $11,000 \mathrm{mi}^{2}$ in northeastern Illinois (62 percent), northwestern Indiana (28 percent), southeastern Wisconsin (10 percent), and southwestern Michigan (less than 0.1 percent). The upper Illinois River Basin comprises the drainage areas upstream from Ottawa, Illinois of the Illinois River and its tributary streams (fig.1). The primary land use in the upper Illinois River Basin , in 1990, was approximately 75 percent agricultural, mostly corn and soybeans. Urban land use accounted for about 17 percent in 1990, but is increasing rapidly because of recent urban expansion of the Chicago and Milwaukee metropolitan areas. The largest population increases from 1970 to 1990 occurred in McHenry and DuPage Counties, Ill. (fig. 1) (Arnold and others, 1999).

The major aquifers underlying the basin are composed of, from youngest to oldest: Quaternary glacial deposits, Silurian-Devonian dolomite and limestone, and Cambrian-Ordovician sandstone and limestone (Arnold and others, 1999). The SilurianDevonian dolomite and limestone and the CambrianOrdovician sandstone and limestone are referred to in this report collectively as the bedrock aquifers. Shallow ground water from the Quaternary glacial deposits potentially can recharge the bedrock aquifers. Heavy use of the bedrock aquifers prior to 1970 has necessitated the use of surface-water supplies and potentially increased use of ground water from glacial deposits.

The upper Illinois River Basin lies within the Central Lowland physiographic province and consists of areas of the Great Lake Section and the Till Plains Section. The Great Lake Section is composed of the Chicago Lake Plain and the Wheaton Morainal Plain. The Till Plains Section is composed of the Bloomington Ridged Plain and the Kankakee Till Plain (fig. 2) (Arnold and others, 1999). 


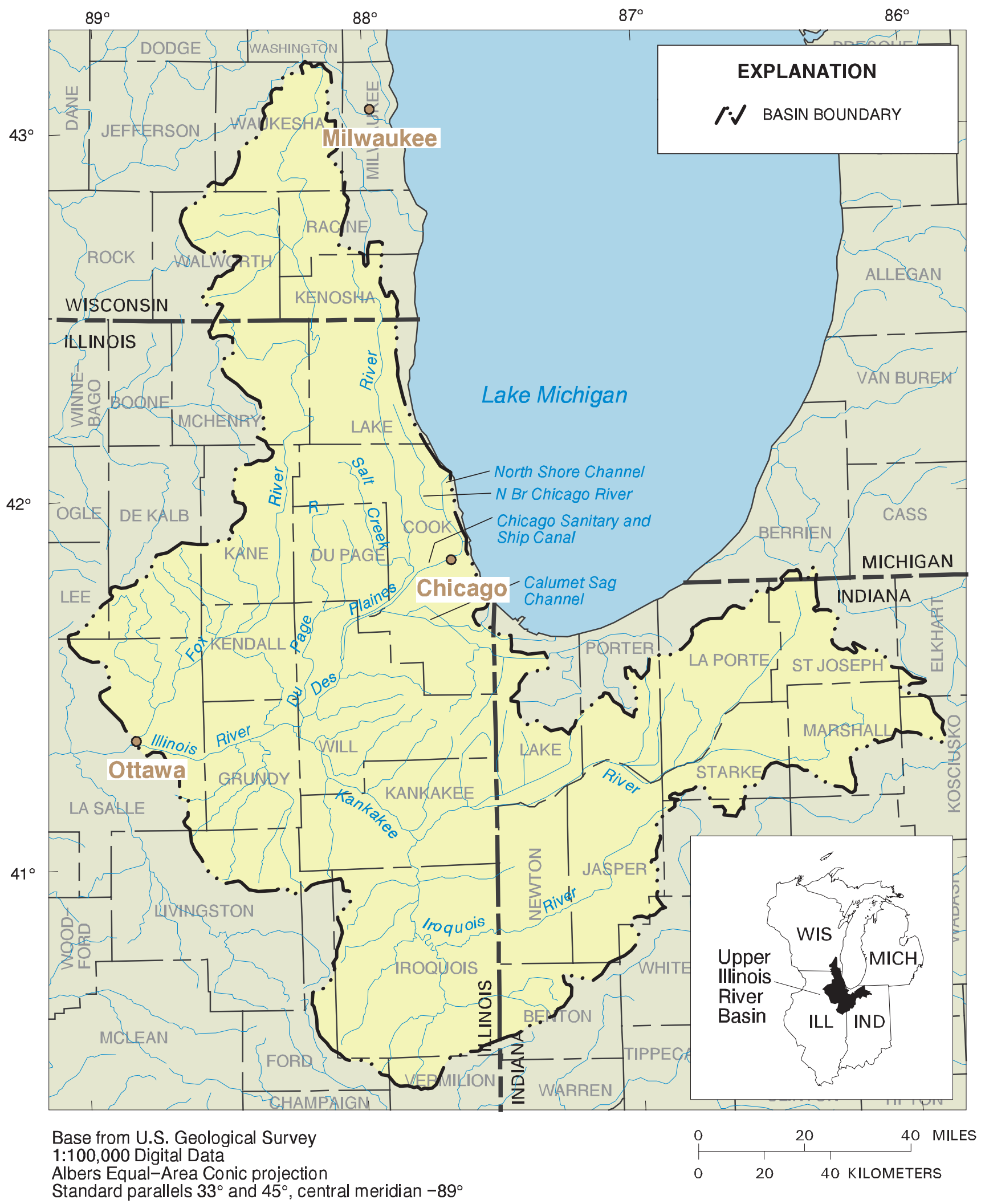

Figure 1. Location of the upper Illinois River Basin. 


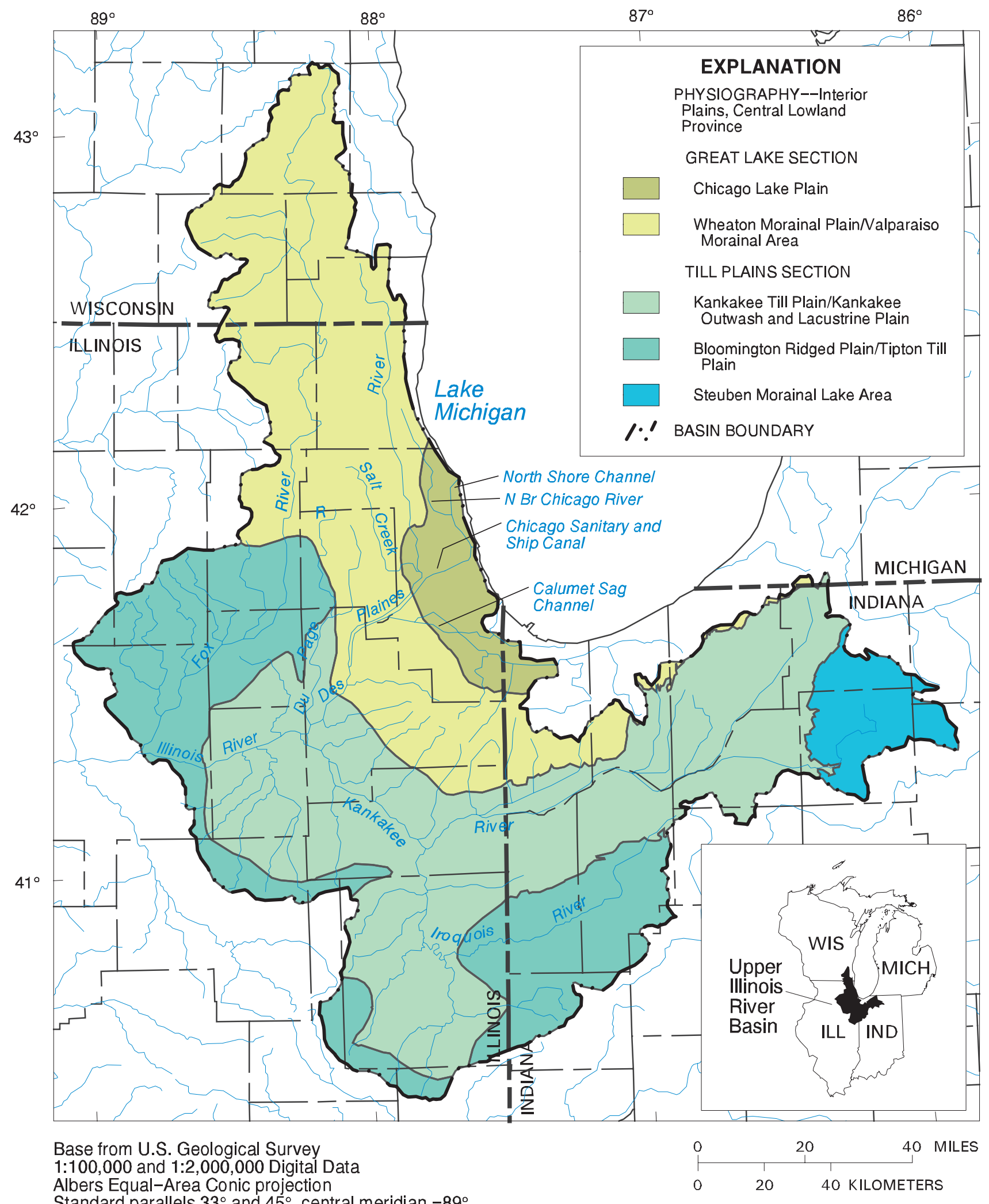

Standard parallels $33^{\circ}$ and $45^{\circ}$, central meridian $-89^{\circ}$

Figure 2. Physiography of the upper Illinois River Basin (modified from Fenneman, 1938; Leighton and others, 1948; and Schneider, 1966). 
The study area in northeastern Illinois and southeastern Wisconsin lies mostly within the Wheaton Morainal Plain (99 percent); a small part of the study area is in the Chicago Lake Plain (less than 1 percent) (fig. 3). The Wheaton Morainal Plain is composed of Wisconsinan Episode moraines and consists of clayey till of the Wadsworth Till Member/ Oak Creek Formation, and sand and gravel of the Haeger Till Member/New Berlin Formation. The Chicago Lake Plain is a flat, glacio-lacustrine deposit consisting primarily of clay and silt of the Carmi and Dolton members of the Equality/Atherton Formation (Arnold and others, 1999). Expanding population growth in the metropolitan areas of the upper Illinois River Basin will make the shallow glacial ground water more important as surface-water supplies and bedrock ground-water supplies are used to their maximum extent.

\section{Acknowledgments}

Thanks are extended to the private homeowners and land managers in the upper Illinois River Basin who allowed the USGS to sample their water-supply wells or allowed access to their land to install and sample monitoring wells.

\section{STUDY DESIGN, AND SAMPLING AND ANALYTICAL METHODS}

Shallow ground water in the Quaternary deposits overlying a major bedrock aquifer located in the Great Lake Section underlies the study area that had recently changed from agricultural land use to urban land use (Vogelmann and others, 2001; Fegeas and others, 1983). The bedrock aquifers underlying the study area are not included in the scope of this report. This recently urbanized study area was delineated based on the methods outlined in Squillace and Price (1996). Urban land use from the 1990 Geographical Information Retrieval and Analysis System (GIRAS) land-use/land-use change coverage (Hitt, 1995) originally was used to define the urban-land use area for this study. This urban land-use data was derived from 1970's land-use information and updated based on increasing population density obtained from 1990 population data. Because the 1990's land-use/land-use change data were dated, the urban areas defined around the rapidly urbanizing area of metropolitan Chicago were underrepresented. At a later time in the study, 1993 land-use data (Vogelmann and others, 2001) became available. Although the land-use data were out-of-date by approximately 5 years, these 1993 land-use data defined urban areas temporally better than the 1990's land-use data. To better estimate the extent of urban areas around Chicago for the sampling time period of this study, a geographic information system (GIS) was used to combine these two land-use data sets and expand (buffer) the urban land-use areas by 500 meters (1,640 ft) on all sides (fig. 3).

\section{Well Selection and Installation}

Water samples were collected from 26 monitoring wells installed specifically for the study and 17 private domestic-supply wells. All wells or well locations were confirmed visually to be within urban areas and selected for sampling on the basis of a random site-selection method developed by Scott (1990). Wells were chosen or installed within $0.5 \mathrm{mi}$ of a randomly selected point as determined by the siteselection program. All wells were completed in glacial sediments at depths less than or equal to $175 \mathrm{ft}$, with 93 percent (40 of 43) of the wells less than $100 \mathrm{ft}$ deep.

Domestic-supply wells selected for sampling must have been completed in the glacial deposits and constructed after 1980 to ensure that modern wellconstruction techniques were used. Water samples were obtained before, or by bypassing, residential watertreatment systems to avoid any chemical modifications introduced by these systems. The 17 domestic-supply wells were completed in sands and gravels of the glacial deposits. Well depths ranged from 31 to $175 \mathrm{ft}$, with a median depth of $72 \mathrm{ft}$. Well diameters ranged from 5 to 7 in., with a median diameter of 6 in. Well-screen lengths ranged from 0 (open end) to $7 \mathrm{ft}$, with a median screen length of $3 \mathrm{ft}$ (table 1).

Table 1. Well dimensions for sampled wells in the upper Illinois River Basin

\begin{tabular}{lccccccc}
\hline \multicolumn{1}{c}{ Type of well } & $\begin{array}{c}\text { Number } \\
\text { of wells }\end{array}$ & $\begin{array}{c}\text { Well depth } \\
\text { (feet below } \\
\text { land surface) }\end{array}$ & $\begin{array}{c}\text { Median } \\
\text { well depth } \\
\text { (in feet) }\end{array}$ & $\begin{array}{c}\text { Well } \\
\text { diameter } \\
\text { (in inches) }\end{array}$ & $\begin{array}{c}\text { Median well } \\
\text { diameter } \\
\text { (in inches) }\end{array}$ & $\begin{array}{c}\text { Well screen } \\
\text { length } \\
\text { (in feet) }\end{array}$ & $\begin{array}{c}\text { Well screen } \\
\text { median } \\
\text { (in feet) }\end{array}$ \\
\hline Domestic supply & 17 & $31-175$ & 72 & $5-7$ & 6 & $0-7$ & 3 \\
Monitoring & 26 & $13.2-58.5$ & 28.6 & 2 & 2 & 5 & 5 \\
\hline
\end{tabular}




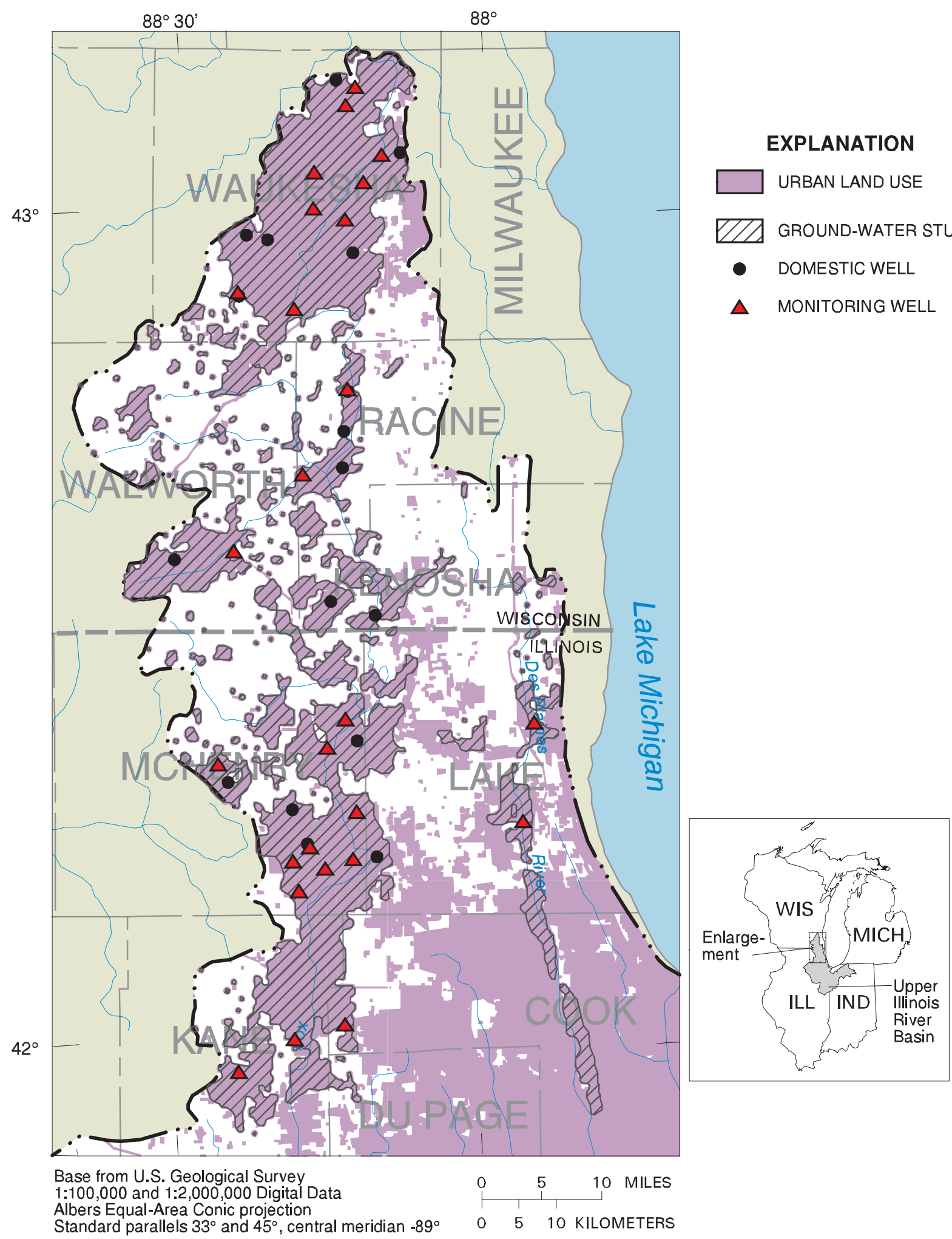

Figure 3. Urban land-use study area and well locations in urbanized areas in northern Illinois/southern Wisconsin (modified from Vogelman and others, 2001; and Hitt, 1995). 
The USGS constructed 26 monitoring wells for this study. The wells were completed in glacial deposits at the first water-producing layer. All monitoring wells were installed and constructed by the USGS on private land and on urban roadsides according to NAWQA protocols (Lapham and others, 1995) using hollowstem auger drilling methods. Wells were screened in deposits ranging from clayey-silt to sand and gravel. Well depths ranged from 13.2 to $58.5 \mathrm{ft}$, with a median depth of $28.6 \mathrm{ft}$. All monitoring wells were constructed of 2-in-diameter polyvinyl chloride (PVC) with 5-ft long screens (table 1).

\section{Sampling and Analysis Methods}

Water samples were collected using standard NAWQA protocols (Koterba and others, 1995) using primarily Teflon and stainless-steel sampling equipment. The samples were collected after fieldmeasured parameters $(\mathrm{pH}$, dissolved oxygen, water temperature, specific conductivity, and turbidity) had stabilized, usually after three well volumes were pumped, to ensure that a representative sample from the aquifer was obtained. Domestic-supply wells were sampled using the well owner's submersible pump. Monitoring wells were sampled using a Fultz submersible pump. In five of the monitoring wells, a Teflon bailer was used to collect the water sample, because flow into the well was too small to use the Fultz pump. In cases where bailing was necessary, the wells also were purged by bailing. No samples for analysis of VOCs were collected at these wells because of the potential for contaminating samples or loss of volatile organic compounds by aeration.

Two levels of reporting detections were used in this report. The highest censoring level of reporting used is the laboratory reporting level (LRL). The LRL is set at a level so that a risk of a false positive (analyte reported present when not in the sample) or false negative (analyte reported not present when present in sample at reporting level) detection is less than or equal to 1 percent. The LRL is twice the long-term method detection level (LT-MDL). The LT-MDL is set at a level that a risk of a false positive detection is no more than 1 percent; however, the risk of a false negative detection is as great as 50 percent. A lower level of reporting, but less precise, is the information-rich method level. Detections using the information-rich method reporting level include, in addition to concentrations above the LRL, estimated concentrations above and below the LT-
MDL. These detections are reported if other qualitycontrol criteria, particularly laboratory blank data, are met. These data have an increased risk of false positive detections (Childress and others, 1999). LRLs for VOCs in this report vary widely, ranging from 0.02 to 7 micrograms per liter $(\mu \mathrm{g} / \mathrm{L})$ with a median of $0.09 \mu \mathrm{g} /$ L. LRLs for pesticides in this report vary widely, ranging from 0.001 to $7.11 \mu \mathrm{g} / \mathrm{L}$ with a median of 0.013 $\mu \mathrm{g} / \mathrm{L}$. LRLs vary among the different VOCs and pesticides. LRLs even can vary for the same VOC or pesticide, because of refinement of analysis methods and possible complications with individual analyses. LRLs for each constituent analyzed are listed in table 2 .

Detections for VOC and pesticide analyses are reported using both the LRLs and information-rich method reporting levels. Nitrate is reported using the LRL.

\section{Volatile Organic Compounds}

Water samples for analysis of volatile organic compounds were obtained by collecting unfiltered water in a 40-ml amber bottle with a septum cap such that air bubbles are not present in the sample to allow degassing of VOCs. Samples were acidified with hydrochloric acid for preservation and shipped chilled to the USGS National Water-Quality Laboratory (NWQL) in Denver, Colo. The water samples were analyzed for 83 VOCs by purge-and-trap isolation and concentration, and capillary-column gas chromatography/mass spectrometry methods (Connor and others, 1998).

\section{Pesticides}

Water samples for analysis of pesticides and pesticide transformation products were obtained by filtering the sample into amber baked glass containers through glass-fiber filters with a $0.7-\mu \mathrm{m}$ pore diameter. Samples for 94 pesticide and 4 transformation product analyses were shipped chilled to the USGS NWQL in Denver, Colo. for analysis by gas chromatography/mass spectrometry GCMS (Zaugg and others, 1995), and high-performance liquid chromatography/mass spectrometry (HPLC/MS) (Furlong and others, 2001). Samples for 10 ethane sulfonic acid (ESA) and oxanilic acid (OA) transformation product analyses were sent to the USGS Organic Geochemistry Research Laboratory in Lawrence, Kans. for analysis by HPLC/MS (Lee and others, 2001). 
Table 2. List of pesticides, pesticide transformation products, and volatile organic compounds with associated laboratory reporting level (LRL) ranges for 1999-2001

$[<$, less than $]$

\begin{tabular}{|c|c|c|c|}
\hline Pesticide & $\begin{array}{c}\text { LRL range } \\
\text { (micrograms per liter) }\end{array}$ & Volatile organic compound & $\begin{array}{c}\text { LRL range } \\
\text { (micrograms per liter) }\end{array}$ \\
\hline 2,4-D & $<0.02-<0.15$ & 1,1-Dichloroethane & $<0.04-<0.066$ \\
\hline 2,4-D Methyl Ester & $<0.009-<0.173$ & 1,1-Dichloroethene & $<0.04$ \\
\hline 2,4-DB & $<0.02-<0.11$ & 1,1-Dichloropropene & $<0.026-<0.03$ \\
\hline 2,6-Diethylaniline & $<0.002-<0.003$ & 1,1,1-Trichloroethane & $<0.03-<0.032$ \\
\hline 3-Hydroxycarbofuran & $<0.01-<0.12$ & 1,1,1,2-Tetrachloroethane & $<0.03$ \\
\hline 3-Ketocarbofuran & $<0.072-<1.5$ & 1,1,2-Trichloro-1,2,2-Trifluoroethane & $<0.06$ \\
\hline 3,4-Chlorophenyl Methyl Urea & $<0.0242-<0.183$ & 1,1,2-Trichloroethane & $<0.06$ \\
\hline Acetochlor & $<0.002-<0.004$ & 1,1,2,2-Tetrachloroethane & $<0.09$ \\
\hline Acetochlor Ethane Sulfonic Acid & $<0.05$ & 1,2-Dibromo-3-Chloropropane & $<0.2-<0.21$ \\
\hline Acetochlor Oxanilic Acid & $<0.05$ & 1,2-Dibromoethane & $<0.036-<0.04$ \\
\hline Acifluorfen & $<0.01-<0.12$ & 1,2-Dichlorobenzene & $<0.03-<0.048$ \\
\hline Alachlor & $<0.002$ & 1,2-Dichloroethane & $<0.1-<0.13$ \\
\hline Alachlor Ethane Sulfonic Acid & $<0.05$ & 1,2-Dichloropropane & $<0.03-<0.068$ \\
\hline Alachlor Oxanilic Acid & $<0.05$ & 1,2-Dimethylbenzene & $<0.038-<0.04$ \\
\hline Aldicarb & $<0.04-<0.16$ & 1,2,3-Trichlorobenzene & $<0.27-<0.3$ \\
\hline Aldicarb Sulfone & $<0.02-<0.32$ & 1,2,3-Trichloropropane & $<0.16-<0.2$ \\
\hline Aldicarb Sulfoxide & $<0.01-<0.05$ & 1,2,3-Trimethylbenzene & $<0.1-<0.12$ \\
\hline Alpha BHC & $<0.002-<0.005$ & 1,2,3,4-Tetramethylbenzene & $<0.2-<0.23$ \\
\hline Atrazine & $<0.001-<0.009$ & 1,2,3,5-Tetramethylbenzene & $<0.2$ \\
\hline Bendiocarb & $<0.025-<0.122$ & 1,2,4-Trichlorobenzene & $<0.19-<0.2$ \\
\hline Benfluralin & $<0.002-<0.01$ & 1,2,4-Trimethylbenzene & $<0.056-<0.06$ \\
\hline Benomyl & $<0.004-<0.044$ & 1,3-Dichlorobenzene & $<0.03-<0.054$ \\
\hline Bensulfuron-methyl & $<0.0158-<0.0964$ & 1,3-Dichloropropane & $<0.1-<0.12$ \\
\hline Bentazon & $<0.01-<0.04$ & 1,3,5-Trimethylbenzene & $<0.04-<0.044$ \\
\hline Bromacil & $<0.03-<0.16$ & 1,4-Dichlorobenzene & $<0.05$ \\
\hline Bromoxynil & $<0.02-<0.11$ & 1,4-Dimethylbenzene & $<0.06$ \\
\hline Butylate & $<0.002$ & 2-Butanone & $<1.6-<2$ \\
\hline $\begin{array}{l}\text { Caffeine (not a pesticide or } \\
\text { transformation product) }\end{array}$ & $<0.01-<0.081$ & 2-Hexanone & $<0.7$ \\
\hline Carbaryl & $<0.03-<0.13$ & 2-Propenenitrile & $<1-<1.2$ \\
\hline Carbofuran & $<0.01-<0.11$ & 2,2-Dichloropropane & $<0.05$ \\
\hline Chloramben, Methyl Ester & $<0.02-<0.23$ & 2-Chlorotoluene & $<0.03-<0.042$ \\
\hline Chlorimuron & $<0.01-<0.073$ & 2-Ethyltoluene & $<0.06$ \\
\hline Chlorothalonil & $<0.04-<0.1$ & 3-Chloro-1-propene & $<0.1-<0.2$ \\
\hline Chlorpyrifos & $<0.004-<0.005$ & 4-Chlorotoluene & $<0.06$ \\
\hline Clopyralid & $<0.01-<0.08$ & 4-Methyl-2-Pentanone & $<0.37-<0.4$ \\
\hline Cyanazine & $<0.004-<0.018$ & Acetone & $<7$ \\
\hline Cycloate & $<0.01-<0.11$ & Benzene & $<0.35-<0.04$ \\
\hline Dacthal Mono-Acid & $<0.01-<0.14$ & Bromobenzene & $<0.036-<0.04$ \\
\hline
\end{tabular}


Table 2. List of pesticides, pesticide transformation products, and volatile organic compounds with associated laboratory reporting level (LRL) ranges for 1999-2001-Continued

\begin{tabular}{|c|c|c|c|}
\hline Pesticide & $\begin{array}{c}\text { LRL range } \\
\text { (micrograms per liter) }\end{array}$ & Volatile organic compound & $\begin{array}{c}\text { LRL range } \\
\text { (micrograms per liter) }\end{array}$ \\
\hline DCPA & $<0.002-<0.003$ & Bromochloromethane & $<0.04-<0.044$ \\
\hline Deethylatrazine & $<0.002-<0.028$ & Bromodichloromethane & $<0.048-<0.05$ \\
\hline Deethyldeisopropylatrazine & $<0.01-<0.12$ & Bromoethene & $<0.1$ \\
\hline Deisopropylatrazine & $<0.04-<0.15$ & Bromomethane & $<0.26-<0.3$ \\
\hline Diazinon & $<0.002-<0.005$ & Carbon Disulfide & $<0.07$ \\
\hline Dicamba & $<0.01-<0.19$ & Chlorobenzene & $<0.028-<0.03$ \\
\hline Dichlorprop & $<0.01-<0.1$ & Chlorodibromomethane & $<0.18-<0.2$ \\
\hline Dieldrin & $<0.001-<0.005$ & Chloroethane & $<0.1-<0.12$ \\
\hline Dinoseb & $<0.01-<0.09$ & Chloroethene & $<0.1-<0.11$ \\
\hline Dimethenamid Ethane Sulfonic Acid & $<0.05$ & Chloromethane & $<0.2-<0.5$ \\
\hline Dimethenamid Oxanilic Acid & $<0.05$ & Cis-1,2-Dichloroethene & $<0.038-<0.4$ \\
\hline Diphenamid & $<0.03-<0.12$ & Cis-1,3-Dichloropropene & $<0.09$ \\
\hline Disulfoton & $<0.017-<0.021$ & Dibromomethane & $<0.05$ \\
\hline Diuron & $<0.01-<0.16$ & Dichlorodifluoromethane & $<0.27-<0.03$ \\
\hline EPTC & $<0.002$ & Dichloromethane & $<0.2-<0.38$ \\
\hline Ethalfluralin & $<0.004-<0.009$ & Diethyl ether & $<0.17-<0.2$ \\
\hline Ethoprop & $<0.003-<0.005$ & Diisopropyl Ether & $<0.1$ \\
\hline Fenuron & $<0.03-<0.15$ & Ethylbenzene & $<0.03$ \\
\hline Flufenacet Ethane Sulfonic Acid & $<0.05$ & Ethyl Methacrylate & $<0.18-<0.2$ \\
\hline Flufenacet Oxanilic Acid & $<0.05$ & Ethyl Tert-Butyl Ether & $<0.05-<0.054$ \\
\hline Flumetsulam & $<0.011-<0.173$ & Hexachlorobutadiene & $<0.1-<0.14$ \\
\hline Fluometuron & $<0.03-<0.12$ & Hexachloroethane & $<0.19-<0.2$ \\
\hline Fonofos & $<0.003$ & Iodomethane & $<0.1-<0.12$ \\
\hline Hydroxyatrazine & $<0.008-<0.385$ & Isopropylbenzene & $<0.03-<0.032$ \\
\hline Imazaquin & $<0.016-<0.206$ & Methyl Acrylate & $<1-<1.4$ \\
\hline Imazethapyr & $<0.017-<0.176$ & Methyl Acrylonitrile & $<0.6$ \\
\hline Imidacloprid & $<0.0068-<0.2122$ & Methyl Methacrylate & $<0.3-<0.35$ \\
\hline Lindane & $<0.004$ & Methyl Tert-Butyl Ether & $<0.17-<0.2$ \\
\hline Linuron & $<0.01-<0.14$ & N-Butylbenzene & $<0.19-<0.2$ \\
\hline Malathion & $<0.005-<0.027$ & N-Propylbenzene & $<0.04-<0.042$ \\
\hline MCPA & $<0.02-<0.12$ & Naphthalene & $<0.2-<0.25$ \\
\hline MCPB & $<0.01-<0.125$ & P-Isopropyltoluene & $<0.07$ \\
\hline Metalaxyl & $<0.02-<0.114$ & Sec-Butylbenzene & $<0.03-<0.032$ \\
\hline Methiocarb & $<0.01-<0.159$ & Styrene & $<0.04-<0.042$ \\
\hline Methomyl & $<0.0044-<0.154$ & Tert-Amyl Methyl Ether & $<0.1-<0.11$ \\
\hline Methomyl Oxime & $<0.0102-<0.0204$ & Tert-Butylbenzene & $<0.06$ \\
\hline Methyl Azinphos & $<0.001-<0.05$ & Tetrachloromethane & $<0.06$ \\
\hline Methyl Parathion & $<0.006$ & Tetrahydrofuran & $<2-<2.2$ \\
\hline Metolachlor & $<0.002-<0.013$ & Trans-1,2-Dichloroethene & $<0.03-<0.032$ \\
\hline Metolachlor Ethane Sulfonic Acid & $<0.05$ & Trans-1,3-Dichloropropene & $<0.09$ \\
\hline
\end{tabular}


Table 2. List of pesticides, pesticide transformation products, and volatile organic compounds with associated laboratory reporting level (LRL) ranges for 1999-2001-Continued

\begin{tabular}{|c|c|c|c|}
\hline Pesticide & $\begin{array}{c}\text { LRL range } \\
\text { (micrograms per liter) }\end{array}$ & Volatile organic compound & $\begin{array}{c}\text { LRL range } \\
\text { (micrograms per liter) }\end{array}$ \\
\hline Metolachlor Oxanilic Acid & $<0.005$ & Trans-1,4-Dichloro-2-butene & $<0.7$ \\
\hline Metribuzin & $<0.004-<0.006$ & Tribromomethane & $<0.06$ \\
\hline Metsulfuron-Methyl & $<0.025-<0.228$ & Trichloroethene & $<0.038-<0.04$ \\
\hline Molinate & $<0.002-<0.004$ & Trichlorofluoromethane & $<0.09$ \\
\hline Napropamide & $<0.003-<0.007$ & Trichloromethane & $<0.02-<0.052$ \\
\hline Neburon & $<0.01-<0.149$ & & \\
\hline Nicosulfuron & $<0.013-<0.131$ & & \\
\hline Norflurazon & $<0.02-<0.155$ & & \\
\hline Oryzalin & $<0.02-<0.14$ & & \\
\hline Oxamyl & $<0.01-<0.032$ & & \\
\hline Oxamyl Oxime & $<0.013-<0.129$ & & \\
\hline $\mathrm{P}, \mathrm{P}^{\prime}-\mathrm{DDE}$ & $<0.003-<0.006$ & & \\
\hline Parathion & $<0.003-<0.004$ & & \\
\hline Pebulate & $<0.002-<0.004$ & & \\
\hline Pendimethalin & $<0.004-<0.01$ & & \\
\hline Permethrin & $<0.005-<0.006$ & & \\
\hline Permethrin & $<0.005-<0.006$ & & \\
\hline Phorate & $<0.002-<0.011$ & & \\
\hline Picloram & $<0.02-<0.142$ & & \\
\hline Prometon & $<0.015-<0.018$ & & \\
\hline Pronamide & $<0.003-<0.004$ & & \\
\hline Propachlor & $<0.007-<0.01$ & & \\
\hline Propanil & $<0.004-<0.011$ & & \\
\hline Propargite & $<0.013-<0.023$ & & \\
\hline Propham & $<0.01-<0.143$ & & \\
\hline Propiconazole & $<0.021-<0.129$ & & \\
\hline Propoxur & $<0.01-<0.119$ & & \\
\hline Siduron & $<0.017-<0.187$ & & \\
\hline Simazine & $<0.005-<0.011$ & & \\
\hline Sulfometruron Methyl & $<0.009-<0.078$ & & \\
\hline Tebuthiuron & $<0.006-<0.016$ & & \\
\hline Terbacil & $<0.007-<0.034$ & & \\
\hline Terbufos & $<0.013-<0.017$ & & \\
\hline Thiobencarb & $<0.002-<0.005$ & & \\
\hline Triallate & $<0.001-<0.002$ & & \\
\hline Tribenuron & $<0.01-<0.14$ & & \\
\hline Triclopyr & $<0.02-<0.2$ & & \\
\hline Trifluralin & $<0.002-<0.009$ & & \\
\hline
\end{tabular}




\section{Nitrate}

Water samples also were analyzed for nitrite and nitrate concentrations. These analyses are referred to as "nitrate", because the nitrite concentrations generally are negligible in ground water. Water samples for nitrate analysis were obtained by filtering the sample through a $0.45-\mu \mathrm{m}$ high-capacity, tortuousflow, polysulfone-capsule filter. Samples were shipped chilled to the USGS NWQL in Denver, Colo. for analysis by colorimetric methods (Fishman and Friedman, 1989).

\section{Age Dating of Ground-Water Samples}

Shallow ground water usually is recharged faster and is younger (less than 50 years) than deeper ground water. Because of this fast recharge and resulting young water, tritium/helium-3 and chlorofluorocarbon (CFC) samples, used to determine younger apparent ages, were analyzed to determine apparent ages of the ground-water samples. Tritium/helium-3 samples were obtained concurrently with CFC samples in 15 monitoring wells. When samples were obtained concurrently, and if apparent ages differed, the analysis that was judged the least affected by factors affecting apparent age was used. Factors affecting CFC analyses include $\mathrm{CFC}$ contamination or degradation, whereas the tritium/helium-3 analyses could be affected by gas fractionation or excess terrigenic helium, among other factors. For statistical analysis, the apparent recharge date is used in this report, whereas apparent recharge date will decrease with an increase in apparent age.

CFCs are stable, non-toxic, nonflammable, synthetic constituents developed in the 1930's for refrigeration. Three $\mathrm{CFC}$ constituents were produced: trichlorofluoromethane (CFC-11), dichlorodifluoromethane (CFC-12), and trichlorotrifluoroethane (CFC-13). Production of CFCs ceased in the United States in 1996 (Plummer and Friedman, 1999). CFC dating is possible by reconstructing their estimated atmospheric amounts and, using the known solubilities of CFCs in water, calculating the concentration of CFCs in recharge water with respect to equilibrium with the air.

Samples for analysis of CFCs were obtained by collecting water through a closed system between the well and sampling apparatus. The boro-silicate glass sample bottles were purged with ultra-pure nitrogen gas before and during collection. The sample bottles then were welded shut, sealing the water from atmospheric contact. Samples were sent to the Reston, Va. Chlorofluorocarbon Laboratory and analyzed using purge and trap, gas chromatography techniques (Plummer and Busenberg, 2000; Plummer and Friedman, 1999).

Tritium/helium-3 dating of young ground water is possible because of the additional input over natural sources by atmospheric testing of nuclear devices of tritium into the air, beginning in 1952 and peaking in 1963-64. Tritium concentrations in recharge water, measured in tritium units (TU's), or picocuries per liter ( $\mathrm{pCi} / \mathrm{L})$, approximately parallel this "bomb peak" in 1963-64 and gradually decline to present.

Concentrations of tritium in recently recharged ground water usually are under 10 TU's (Clark and Fritz, 1997). The tritium/helium-3 apparent age is calculated from the radioactive decay of tritium to helium-3 in the water sample. The decay of tritium to helium-3 is used to determine the amount of tritiogenic helium-3 based on a helium isotope mass balance (Schlosser and others, 1988, 1989).

Tritium/helium-3 samples were obtained by collecting water through a closed system between the well and the sampling apparatus. Copper sample tubes were flushed with sample water and then sealed shut while flowing to eliminate atmospheric contact. Samples were sent to the Lamont-Doherty Earth Observatory in Palisades, N.Y., where they were analyzed for measurement of helium isotopes and tritium by the helium ingrowth method (Schlosser and others, 1988, 1989).

\section{Quality-Assurance/Quality-Control Plan}

A quality-assurance plan for constituents analyzed in the study was developed and consisted of blanks, replicates, and (for VOCs and pesticides) spikes, in the field and laboratory to evaluate the bias and variability of the analytical results (Koterba and others, 1995; Connor and others, 1998; Zaugg and others, 1995).

Nine field and source blanks for VOCs were collected concurrently with source solution blanks. Toluene was deleted from the data set because of systematic contamination in the field blank and source 
blank. Trichloromethane (chloroform) was detected in three field blanks at or below the LT-MDL. One blank detection also had a concurrent environmental detection of chloroform. No source blanks had any chloroform detections. Based on these field blanks, source blanks, and environmental samples near the blank concentration, data quality from three samples are considered questionable for chloroform. The rest of the field-blank analyses for other constituents were good.

Nine field blanks were collected for pesticides. There were no detections of any pesticides in the field blank, except for caffeine. Caffeine, although not a pesticide, is included in the pesticides schedule because the same sampling and analytical methods are used for pesticides as well as caffeine because of similar chemical properties between the two constituent types. Caffeine is included in the dataset for this report because it also is indicative of anthropogenic effects. Caffeine was detected in two field blank samples at estimated values of 0.006 and $0.007 \mu \mathrm{g} / \mathrm{L}$ with a LRL of $0.080 \mu \mathrm{g} / \mathrm{L}$. There were no corresponding environmental detections with these detections; therefore, for the purposes of this report, the environmental caffeine detections met data-quality objectives.

Concurrent environmental sample replicates were spiked in the field with known mixtures of pesticides and VOCs to determine recoverability of these constituents. Recoveries for four field-spiked pesticide samples ranged from 48 to 300 percent with an average of 92 percent. The recoveries for four fieldspiked VOC samples ranged from 32 to 113 percent, with an average of 69 percent. Laboratory spiked samples also were analyzed according to laboratory protocols for pesticides and VOCs (Zaugg and others, 1995; Connor and others, 1998). No pesticide or VOC detections were deleted based on poor recoveries.

Nine nitrate field blanks were collected and had no contamination. Four nitrate replicate samples were collected; nitrate concentrations in the replicate samples were within 2 percent of concentrations in the environmental samples. The rest of the constituents that were analyzed, and used in correlations and comparisons with VOCs, pesticides, and nitrate, met data-quality objectives based on their replicate and blank analyses.

\section{Statistical Analysis}

The number of wells sampled during the study consisted of 17 domestic wells and 26 monitoring wells, for a total well population of 43 wells. VOC, pesticide, and nitrate data were not normally distributed among the samples; therefore, nonparametric methods were used in the statistical analyses. The nonparametric Spearman Rank (Sr) correlation coefficient was calculated for VOC, pesticide, and nitrate data with inorganic constituents, field parameters, and well characteristics. Correlations are evaluated as to the degree of significance (p). If the p value was 0.05 or less, the correlation was reported as significant; if the $\mathrm{p}$ value was greater than 0.05 , the $\mathrm{p}$ value is listed with the correlation.

\section{ANTHROPOGENIC CONSTITUENT DETECTIONS}

Two levels of reporting VOC and pesticide detection levels are used in this report; these are the LRL and the information-rich method reporting level. The LRL detections are suited for quantitative interpretations, whereas the information-rich methods are used in this report for qualitative interpretations, and general semi-quantitative interpretations and correlation statistics.

\section{Volatile Organic Compounds}

Using LRLs, of the 38 wells (21 monitoring wells and 17 domestic-supply wells) sampled for VOCs, 12 wells (32 percent) had 15 detections of 7 different VOCs with concentrations ranging from an estimated value of 0.03 to $4.6 \mu \mathrm{g} / \mathrm{L}$ with a median of $0.13 \mu \mathrm{g} / \mathrm{L}$. Of the domestic-supply wells, 7 samples had 10 detections of 6 different VOCs, whereas the monitoring wells had 5 samples with 5 detections of 4 different VOCs (table 3).

All but one of the VOC detections were at concentrations less than or equal to $0.2 \mu \mathrm{g} / \mathrm{L}$. Methyl tert-butyl ether (MTBE) in one sample had a concentration of $4.6 \mu \mathrm{g} / \mathrm{L}$. The most common VOCs detected above LRLs were MTBE, a fuel oxygenate, and chloroform, a trihalomethane commonly formed as a disinfection by-product, each having four detections10 percent of the well samples. The other detections 
Table 3. List of volatile organic compound detections at or above laboratory reporting levels (LRLs) in 38 wells sampled in the upper Illinois River Basin, 2000-2001

[e, estimated concentration]

\begin{tabular}{|c|c|c|c|c|}
\hline Volatile organic compound & Well type & $\begin{array}{l}\text { Number of } \\
\text { detections }\end{array}$ & $\begin{array}{c}\text { Range } \\
\text { (micrograms } \\
\text { per liter) }\end{array}$ & $\begin{array}{c}\text { Median } \\
\text { (micrograms } \\
\text { per liter) }\end{array}$ \\
\hline \multirow{3}{*}{ 1,1-Dichloroethane } & Domestic & 1 & (e) 0.06 & 0.06 \\
\hline & Monitoring & 0 & 0 & 0 \\
\hline & Total & 1 & (e) 0.06 & 0.06 \\
\hline \multirow{3}{*}{ 1,1,1-Trichloroethane } & Domestic & 2 & 0.11 & 0.11 \\
\hline & Monitoring & 1 & 0.197 & 0.197 \\
\hline & Total & 3 & $0.11-0.197$ & 0.11 \\
\hline \multirow{3}{*}{ Carbon Disulfide } & Domestic & 1 & 0.13 & 0.13 \\
\hline & Monitoring & 0 & 0 & 0 \\
\hline & Total & 1 & 0.13 & 0.13 \\
\hline \multirow{3}{*}{ Diisopropyl Ether } & Domestic & 0 & 0 & 0 \\
\hline & Monitoring & 1 & 0.105 & 0.105 \\
\hline & Total & 1 & 0.105 & 0.105 \\
\hline \multirow{3}{*}{ Methyl Tert-Butyl Ether } & Domestic & 3 & $0.2-4.6$ & 0.2 \\
\hline & Monitoring & 1 & 0.199 & 0.199 \\
\hline & Total & 4 & $0.199-4.6$ & 0.2 \\
\hline \multirow{3}{*}{ Tert-Amyl Methyl Ether } & Domestic & 1 & 0.2 & 0.2 \\
\hline & Monitoring & 0 & 0 & 0 \\
\hline & Total & 1 & 0.2 & 0.2 \\
\hline \multirow{3}{*}{ Trichloromethane (chloroform) } & Domestic & 2 & (e) 0.03 & 0.03 \\
\hline & Monitoring & 2 & (e) $0.063-0.15$ & 0.1065 \\
\hline & Total & 4 & (e) $0.03-0.15$ & 0.0465 \\
\hline
\end{tabular}

above the LRLs were: the fuel oxygenates and octane enhancers tert-pentyl methyl ether (TAME) and diisopropyl ether (DIPE), the solvents 1-1,dichloroethane, 1,1,1-trichlorethane, and carbon disulfide, which can occur naturally or from anthropogenic sources.

Using information-rich method levels, of the 38 wells sampled, 28 wells ( 74 percent) had 37 detections of 15 different VOCs. From the domestic-supply wells, 14 samples (82 percent) had 18 detections of 10 different VOCs. From the monitoring wells, 14 samples had 19 detections of 9 different VOCs (table 4). The most common VOC detected at the information-rich method reporting levels was chloroform, with nine detections, or 24 percent of the well samples. Well locations with VOC detections are shown in figure 4.

No detection for any VOC exceeded USEPA Maximum Contaminant Levels (MCLs), Health Advisories (HAs) or other USEPA drinking-water criteria. The highest detection, a $4.6 \mu \mathrm{g} / \mathrm{L}$ concentration of MTBE, was below the USEPA Margin of Exposure of $20 \mu \mathrm{g} / \mathrm{L}$. All other VOC detections were at least two orders of magnitude below USEPA MCLs (U.S. Environmental Protection Agency, 2000). 
Table 4. List of volatile organic compound detections at or above information-rich method levels in 38 wells sampled in the upper Illinois River Basin

[e, estimated concentration]

\begin{tabular}{|c|c|c|c|c|}
\hline Volatile organic compound & Well type & $\begin{array}{l}\text { Number of } \\
\text { detections }\end{array}$ & $\begin{array}{c}\text { Concentration range } \\
\text { (micrograms per liter) }\end{array}$ & $\begin{array}{c}\text { Median concentration } \\
\text { (micrograms per liter) }\end{array}$ \\
\hline \multirow{3}{*}{ 1,1-Dichloroethane } & Domestic & 1 & (e) 0.06 & 0.06 \\
\hline & Monitoring & 1 & (e) 0.064 & 0.064 \\
\hline & Total & 2 & (e) 0.06 - (e) 0.064 & 0.062 \\
\hline \multirow{3}{*}{ 1,1,1-Trichloroethane } & Domestic & 4 & (e) $0.01-0.11$ & 0.06 \\
\hline & Monitoring & 3 & (e) $0.016-0.197$ & 0.03 \\
\hline & Total & 7 & (e) $0.01-0.197$ & 0.03 \\
\hline \multirow{3}{*}{ Benzene } & Domestic & 0 & 0 & 0 \\
\hline & Monitoring & 2 & (e) 0.011 - (e) 0.016 & 0.0135 \\
\hline & Total & 2 & (e) $0.011-(\mathrm{e}) 0.016$ & 0.0135 \\
\hline \multirow{3}{*}{ Carbon Disulfide } & Domestic & 3 & (e) $0.01-0.13$ & 0.05 \\
\hline & Monitoring & 0 & 0 & 0 \\
\hline & Total & 3 & (e) $0.01-0.13$ & 0.05 \\
\hline \multirow{3}{*}{ Chloromethane } & Domestic & 0 & 0 & 0 \\
\hline & Monitoring & 2 & (e) 0.06 - (e) 0.074 & 0.067 \\
\hline & Total & 2 & (e) 0.06 - (e) 0.074 & 0.067 \\
\hline \multirow{3}{*}{ Dichlorodifluoromethane } & Domestic & 1 & (e) 0.1 & 0.1 \\
\hline & Monitoring & 0 & 0 & 0 \\
\hline & Total & 1 & (e) 0.1 & 0.1 \\
\hline \multirow{3}{*}{ Dichloromethane } & Domestic & 1 & (e) 0.1 & 0.1 \\
\hline & Monitoring & 0 & 0 & 0 \\
\hline & Total & 1 & (e) 0.1 & 0.1 \\
\hline \multirow{3}{*}{ Diisopropyl Ether } & Domestic & 0 & 0 & 0 \\
\hline & Monitoring & 1 & 0.105 & 0.105 \\
\hline & Total & 1 & 0.105 & 0.105 \\
\hline \multirow{3}{*}{ Ethylbenzene } & Domestic & 0 & 0 & 0 \\
\hline & Monitoring & 1 & (e) 0.007 & 0.007 \\
\hline & Total & 1 & (e) 0.007 & 0.007 \\
\hline \multirow{3}{*}{ Methyl Tert-Butyl Ether } & Domestic & 3 & $0.2-4.6$ & 0.2 \\
\hline & Monitoring & 1 & 0.199 & 0.199 \\
\hline & Total & 4 & $0.199-4.6$ & 0.2 \\
\hline \multirow{3}{*}{ Styrene } & Domestic & 1 & (e) 0.02 & 0.02 \\
\hline & Monitoring & 0 & 0 & 0 \\
\hline & Total & 1 & (e) 0.02 & 0.02 \\
\hline \multirow{3}{*}{ Tert-Amyl Methyl Ether } & Domestic & 1 & 0.2 & 0.2 \\
\hline & Monitoring & 0 & 0 & 0 \\
\hline & Total & 1 & 0.2 & 0.2 \\
\hline \multirow{3}{*}{ Tetrahydrofuran } & Domestic & 0 & 0 & 0 \\
\hline & Monitoring & 1 & (e) 1.12 & 1.12 \\
\hline & Total & 1 & (e) 1.12 & 1.12 \\
\hline \multirow{3}{*}{ Trichloroethene } & Domestic & 1 & (e) 0.03 & 0.03 \\
\hline & Monitoring & 0 & 0 & 0 \\
\hline & Total & 1 & (e) 0.03 & 0.03 \\
\hline \multirow{3}{*}{ Trichloromethane (chloroform) } & Domestic & 2 & (e) 0.03 & 0.03 \\
\hline & Monitoring & 7 & (e) $0.009-0.15$ & 0.011 \\
\hline & Total & 9 & (e) $0.009-0.15$ & 0.016 \\
\hline
\end{tabular}




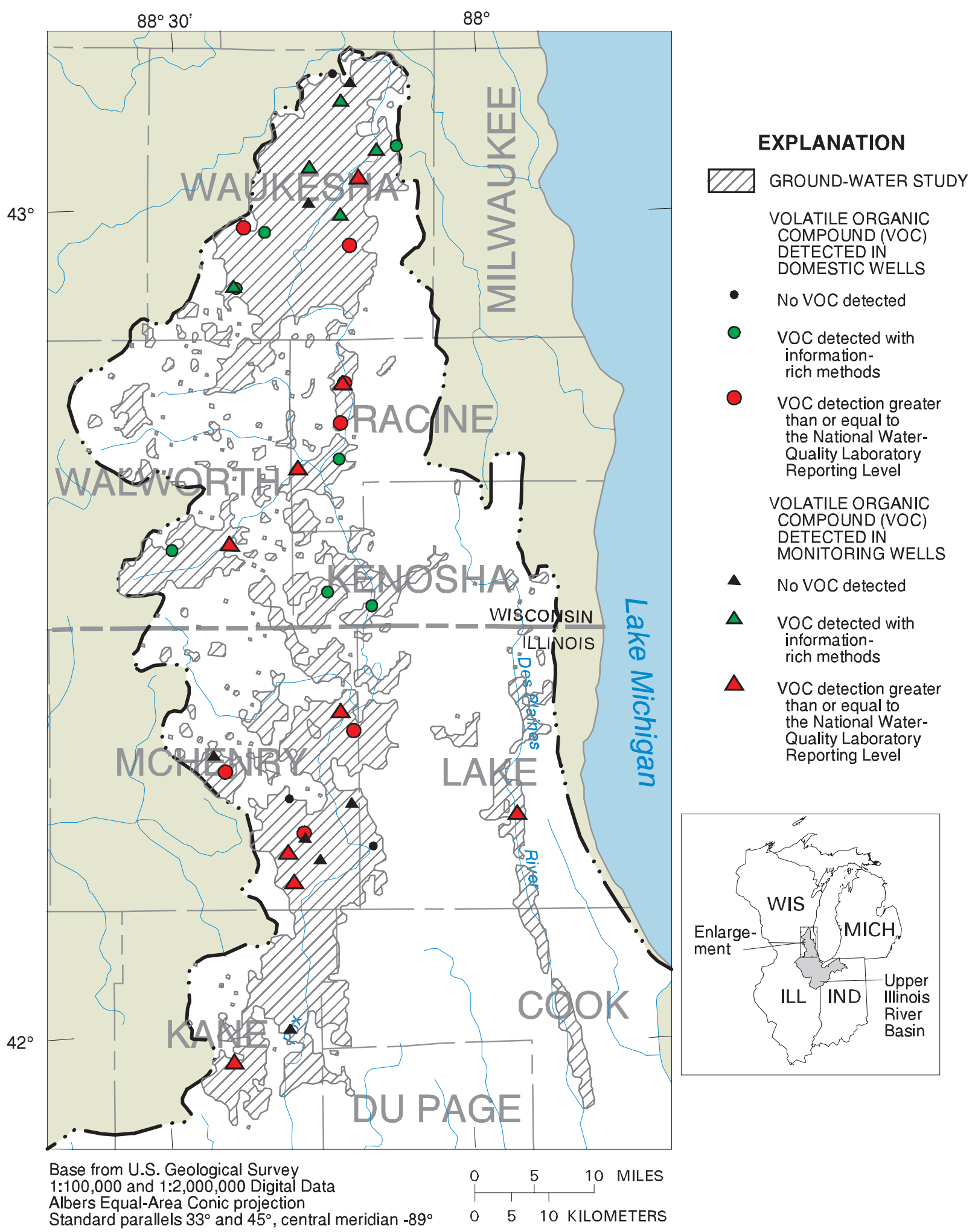

Figure 4. Volatile organic compound detections in wells in urbanized areas in northern Illinois/southern Wisconsin. 


\section{Pesticides}

Using LRLs, of 42 wells (25 monitoring wells and 17 domestic-supply wells) sampled for pesticides, 26 samples (62 percent) had 83 detections of 20 pesticides with concentrations ranging from 0.003 (estimated) to 3.6 (estimated) $\mu \mathrm{g} / \mathrm{L}$ with a median concentration of $0.06 \mu \mathrm{g} / \mathrm{L}$. The domestic wells had 8 samples with 17 detections of 8 pesticides. The monitoring wells had 18 samples with 66 detections of 20 pesticides (table 5).

Pesticide concentrations at or above LRLs were greater than $1.0 \mu \mathrm{g} / \mathrm{L}$ in 5 (6 percent) of the detections and 22 (29 percent) of the concentrations were greater than $0.2 \mu \mathrm{g} / \mathrm{L}$. The most common pesticide detected above LRLs was deethylatrazine, a pesticide transformation product detected in 18 (43 percent) samples. Atrazine, the original pesticide, was detected in 13 (31 percent) samples. The pesticide transformation product metolachlor ESA was detected in 12 (29 percent) samples. The summed concentrations of all metolachlor ESA detection were higher than the sum total of any pesticide (original pesticide or transformation product), with median and average concentrations of 0.31 and $0.63 \mu \mathrm{g} / \mathrm{L}$, respectively.

At information-rich method levels, 31 samples

(74 percent) had 134 detections of 29 different pesticides. Of the domestic wells, 10 samples (59 percent) had 32 detections of 12 different pesticides, whereas 21 samples ( 84 percent) from monitoring wells had 102 detections of 27 different pesticides (table 6). The most common pesticide constituent, detected at information-rich method reporting levels, was deethylatrazine (a transformation product of atrazine), with 19 detections (45 percent) among the 42 samples. Atrazine was detected in 16 samples (38 percent). Atrazine, and its transformation products deethylatrazine, deethyldeisopropylatrazine, deisopropylatrazine, and hydroxyatrazine, accounted for 63 of the 128 (49 percent) pesticide detections. Prometon was detected in 12 samples (29 percent). Prometon, although it is not used in crop pesticide applications, is used on industrial sites, non-crop areas of farms, in and under asphalt, and by homeowners. The frequent detections of prometon probably result because of its large use for non-agricultural purposes, persistence and solubility (Capel and others, 1999). Locations of wells where pesticides were sampled and detected are shown in figure 5.

Pesticide transformation products were detected in 24 of the 42 samples. Of these 24 samples, 2 or more pesticide transformation products were detected concurrently in 18 (75 percent) of the samples with at least 1 detection. Three (12 percent) of these 24 samples had 8 detections. Although ESA and OA concentrations were not reported below the LRL, combined concentrations of these transformation products were more than twice the sum of original pesticide products reported at information-rich method reporting levels (2.2 times) and LRLs (2.3 times). Pesticide transformation product detections at LRLs comprised 65 percent (50 of 77) of total pesticide detections.

No pesticide detection exceeded USEPA drinking water MCLs, HAs, or other USEPA drinkingwater criteria. The highest detection, an estimated $3.6 \mu \mathrm{g} / \mathrm{L}$ concentration of MCPA, was near the lifetime HA level of $4 \mu \mathrm{g} / \mathrm{L}$. All other pesticide detections were at least two orders of magnitude below USEPA MCLs (U.S. Environmental Protection Agency, 2000).

\section{Nitrate}

Nitrate concentrations were reported above LRLs ranging from 0.047 to 0.05 milligrams per liter $(\mathrm{mg} / \mathrm{L})$. Nitrate concentrations ranged from less than 0.047 to $12.5 \mathrm{mg} / \mathrm{L}$ with a median concentration of $0.068 \mathrm{mg} / \mathrm{L}$. Of the 43 wells sampled for nitrate, 13 samples (30 percent) had nitrate concentrations exceeding the estimated national background concentration level of $2 \mathrm{mg} / \mathrm{L}$ (Mueller and Helsel, 1996). One sample exceeded the USEPA MCL of $10 \mathrm{mg} / \mathrm{L}$ (U.S. Environmental Protection Agency, 2000). Of the 17 domestic wells, 5 samples (29 percent) had concentrations greater than $2.0 \mathrm{mg} / \mathrm{L}$, whereas the 26 monitoring wells had 8 samples (31 percent) with concentrations greater than $2.0 \mathrm{mg} / \mathrm{L}$, with one sample exceeding $10 \mathrm{mg} / \mathrm{L}$. Locations of wells where nitrate samples were collected and detected are shown in figure 6. 
Table 5. List of pesticide and pesticide transformation product detections at or above laboratory reporting levels (LRLs) in 42 wells sampled in the upper Illinois River Basin

[e, estimated concentration]

\begin{tabular}{|c|c|c|c|c|}
\hline $\begin{array}{l}\text { Pesticide or pesticide } \\
\text { transformation product }\end{array}$ & Well type & $\begin{array}{l}\text { Number of } \\
\text { detections }\end{array}$ & $\begin{array}{l}\text { Concentration range } \\
\text { (micrograms per liter) }\end{array}$ & $\begin{array}{c}\text { Median concentration } \\
\text { (micrograms per liter) }\end{array}$ \\
\hline \multirow{3}{*}{ Acetochlor } & Domestic & 0 & 0 & 0 \\
\hline & Monitoring & 2 & $0.004-0.01$ & 0.007 \\
\hline & Total & 2 & $0.004-0.01$ & 0.007 \\
\hline \multirow{3}{*}{ Acetochlor Ethane Sulfonic Acid } & Domestic & 1 & 0.13 & 0.13 \\
\hline & Monitoring & 1 & 0.06 & 0.06 \\
\hline & Total & 2 & $0.06-0.13$ & 0.95 \\
\hline \multirow{3}{*}{ Acetochlor Oxanilic Acid } & Domestic & 0 & 0 & 0 \\
\hline & Monitoring & 1 & 0.36 & 0.36 \\
\hline & Total & 1 & 0.36 & 0.36 \\
\hline \multirow{3}{*}{ Alachlor Ethane Sulfonic Acid } & Domestic & 1 & 0.05 & 0.05 \\
\hline & Monitoring & 6 & $0.08-0.53$ & 0.22 \\
\hline & Total & 7 & $0.05-0.43$ & 0.22 \\
\hline \multirow{3}{*}{ Alachlor Oxanilic Acid } & Domestic & 0 & 0 & 0 \\
\hline & Monitoring & 2 & $0.07-0.43$ & 0.25 \\
\hline & Total & 2 & $0.07-0.43$ & 0.25 \\
\hline \multirow{3}{*}{ Atrazine } & Domestic & 2 & $0.009-0.013$ & 0.011 \\
\hline & Monitoring & 11 & $0.004-0.03$ & 0.007 \\
\hline & Total & 13 & $0.004-0.03$ & 0.009 \\
\hline \multirow{3}{*}{ Bromacil } & Domestic & 0 & 0 & 0 \\
\hline & Monitoring & 1 & (e) 0.51 & 0.51 \\
\hline & Total & 1 & (e) 0.51 & 0.51 \\
\hline \multirow{3}{*}{ Butylate } & Domestic & 0 & 0 & 0 \\
\hline & Monitoring & 1 & 0.007 & 0.007 \\
\hline & Total & 1 & 0.007 & 0.007 \\
\hline \multirow{3}{*}{ Deethylatrazine } & Domestic & 4 & (e) 0.008 - (e) 0.02 & 0.0175 \\
\hline & Monitoring & 14 & (e) 0.003 - (e) 0.108 & 0.0055 \\
\hline & Total & 18 & (e) 0.003 - (e) 0.108 & 0.0085 \\
\hline \multirow{3}{*}{ Deethyldeisopropylatrazine } & Domestic & 2 & (e) 0.11 & 0.11 \\
\hline & Monitoring & 3 & (e) $0.08-0.14$ & 0.13 \\
\hline & Total & 5 & (e) $0.08-0.14$ & 0.11 \\
\hline \multirow{3}{*}{ Hydroxyatrazine } & Domestic & 1 & (e) 0.02 & 0.02 \\
\hline & Monitoring & 1 & (e) 0.556 & 0.556 \\
\hline & Total & 2 & (e) 0.02 - (e) 0.556 & 0.288 \\
\hline
\end{tabular}


Table 5. List of pesticide and pesticide transformation product detections at or above laboratory reporting levels (LRLs) in 42 wells sampled in the upper Illinois River Basin-Continued

\begin{tabular}{|c|c|c|c|c|}
\hline $\begin{array}{l}\text { Pesticide or pesticide } \\
\text { transformation product }\end{array}$ & Well type & $\begin{array}{l}\text { Number of } \\
\text { detections }\end{array}$ & $\begin{array}{l}\text { Concentration range } \\
\text { (micrograms per liter) }\end{array}$ & $\begin{array}{l}\text { Median concentration } \\
\text { (micrograms per liter) }\end{array}$ \\
\hline \multirow{3}{*}{ Imazaquin } & Domestic & 0 & 0 & 0 \\
\hline & Monitoring & 1 & (e) 0.15 & 0.15 \\
\hline & Total & 1 & (e) 0.15 & 0.15 \\
\hline \multirow{3}{*}{ MCPA } & Domestic & 0 & 0 & 0 \\
\hline & Monitoring & 1 & (e) 3.6 & 3.6 \\
\hline & Total & 1 & (e) 3.6 & 3.6 \\
\hline \multirow{3}{*}{ Metolachlor } & Domestic & 0 & 0 & 0 \\
\hline & Monitoring & 4 & $0.005-0.01$ & 0.007 \\
\hline & Total & 4 & $0.005-0.01$ & 0.007 \\
\hline \multirow{3}{*}{ Metolachlor Ethane Sulfonic Acid } & Domestic & 4 & $0.06-0.6$ & 0.12 \\
\hline & Monitoring & 8 & $0.1-2.86$ & 0.53 \\
\hline & Total & 12 & $0.06-2.86$ & 0.31 \\
\hline \multirow{3}{*}{ Metolachlor Oxanilic Acid } & Domestic & 0 & 0 & 0 \\
\hline & Monitoring & 3 & $0.25-1.71$ & 0.62 \\
\hline & Total & 3 & $0.25-1.71$ & 0.62 \\
\hline \multirow{3}{*}{ Oryzalin } & Domestic & 0 & 0 & 0 \\
\hline & Monitoring & 1 & 0.22 & 0.22 \\
\hline & Total & 1 & 0.22 & 0.22 \\
\hline \multirow{3}{*}{ Prometon } & Domestic & 2 & $0.031-0.091$ & 0.061 \\
\hline & Monitoring & 2 & $0.069-0.094$ & 0.0815 \\
\hline & Total & 4 & $0.031-0.094$ & 0.08 \\
\hline \multirow{3}{*}{ Terbacil } & Domestic & 0 & 0 & 0 \\
\hline & Monitoring & 2 & (e) 0.007 - (e) 0.008 & 0.0075 \\
\hline & Total & 2 & (e) $0.007-(\mathrm{e}) 0.008$ & 0.0075 \\
\hline \multirow{3}{*}{ Triclopyr } & Domestic & 0 & 0 & 0 \\
\hline & Monitoring & 1 & (e) 1.13 & 1.13 \\
\hline & Total & 1 & (e) 1.13 & 1.13 \\
\hline
\end{tabular}


Table 6. List of pesticide and pesticide transformation product detections at or above information-rich method levels in 42 wells sampled in the upper Illinois River Basin

[e, estimated concentration]

\begin{tabular}{|c|c|c|c|c|}
\hline $\begin{array}{l}\text { Pesticide or pesticide } \\
\text { transformation product }\end{array}$ & Well type & $\begin{array}{l}\text { Number of } \\
\text { detections }\end{array}$ & $\begin{array}{l}\text { Concentration range } \\
\text { (micrograms per liter) }\end{array}$ & $\begin{array}{l}\text { Median concentration } \\
\text { (micrograms per liter) }\end{array}$ \\
\hline \multirow{3}{*}{ 2,4-D } & Domestic & 0 & 0 & 0 \\
\hline & Monitoring & 1 & (e) 0.05 & 0.05 \\
\hline & Total & 1 & (e) 0.05 & 0.05 \\
\hline \multirow{3}{*}{ Acetochlor } & Domestic & 0 & 0 & 0 \\
\hline & Monitoring & 2 & $0.004-0.01$ & 0.007 \\
\hline & Total & 2 & $0.004-0.01$ & 0.007 \\
\hline \multirow{3}{*}{ Acetochlor Ethane Sulfonic Acid } & Domestic & 1 & 0.13 & 0.13 \\
\hline & Monitoring & 1 & 0.06 & 0.06 \\
\hline & Total & 2 & $0.06-0.13$ & 0.95 \\
\hline \multirow{3}{*}{ Acetochlor Oxanilic Acid } & Domestic & 0 & 0 & 0 \\
\hline & Monitoring & 1 & 0.36 & 0.36 \\
\hline & Total & 1 & 0.36 & 0.36 \\
\hline \multirow{3}{*}{ Acifluorfen } & Domestic & 0 & 0 & 0 \\
\hline & Monitoring & 1 & (e) 0.02 & 0.02 \\
\hline & Total & 1 & (e) 0.02 & 0.02 \\
\hline \multirow{3}{*}{ Alachlor Ethane Sulfonic Acid } & Domestic & 1 & 0.05 & 0.05 \\
\hline & Monitoring & 6 & $0.08-0.53$ & 0.22 \\
\hline & Total & 7 & $0.05-0.43$ & 0.22 \\
\hline \multirow{3}{*}{ Alachlor Oxanilic Acid } & Domestic & 0 & 0 & 0 \\
\hline & Monitoring & 2 & $0.07-0.43$ & 0.25 \\
\hline & Total & 2 & $0.07-0.43$ & 0.25 \\
\hline \multirow{3}{*}{ Atrazine } & Domestic & 5 & (e) $0.002-0.013$ & 0.005 \\
\hline & Monitoring & 11 & (e) $0.004-0.03$ & 0.006 \\
\hline & Total & 16 & (e) $0.002-0.03$ & 0.006 \\
\hline \multirow{3}{*}{ Bromacil } & Domestic & 0 & 0 & 0 \\
\hline & Monitoring & 2 & (e) $0.01-$ (e) 0.51 & 0.26 \\
\hline & Total & 2 & (e) $0.01-$ (e) 0.51 & 0.26 \\
\hline \multirow{3}{*}{ Butylate } & Domestic & 0 & 0 & 0 \\
\hline & Monitoring & 1 & 0.007 & 0.007 \\
\hline & Total & 1 & 0.007 & 0.007 \\
\hline \multirow{3}{*}{$\begin{array}{l}\text { Caffeine (not a pesticide or } \\
\text { transformation product) }\end{array}$} & Domestic & 0 & 0 & 0 \\
\hline & Monitoring & 4 & (e) 0.004 - (e) 0.024 & 0.0095 \\
\hline & Total & 4 & (e) 0.004 - (e) 0.024 & 0.0095 \\
\hline \multirow{3}{*}{ Deethylatrazine } & Domestic & 5 & (e) $0.002-(\mathrm{e}) 0.02$ & 0.015 \\
\hline & Monitoring & 14 & (e) 0.003 - (e) 0.108 & 0.0055 \\
\hline & Total & 19 & (e) $0.002-$ (e) 01.08 & 0.008 \\
\hline \multirow{3}{*}{ Deethyldeisopropylatrazine } & Domestic & 2 & 0.11 & 0.11 \\
\hline & Monitoring & 9 & (e) 0.01 - (e) 0.14 & 0.05 \\
\hline & Total & 11 & (e) $0.01-$ (e) 0.14 & 0.05 \\
\hline \multirow{3}{*}{ Deisopropylatrazine } & Domestic & 2 & (e) $0.01-$ (e) 0.02 & 0.015 \\
\hline & Monitoring & 4 & (e) $0.01-$ (e) 0.04 & 0.02 \\
\hline & Total & 6 & (e) 0.01 - (e) 0.04 & 0.015 \\
\hline
\end{tabular}


Table 6. List of pesticide and pesticide transformation product detections at or above information-rich method levels in 42 wells sampled in the upper Illinois River Basin-Continued

\begin{tabular}{|c|c|c|c|c|}
\hline $\begin{array}{l}\text { Pesticide or pesticide } \\
\text { transformation product }\end{array}$ & Well type & $\begin{array}{l}\text { Number of } \\
\text { detections }\end{array}$ & $\begin{array}{l}\text { Concentration range } \\
\text { (micrograms per liter) }\end{array}$ & $\begin{array}{l}\text { Median concentration } \\
\text { (micrograms per liter) }\end{array}$ \\
\hline \multirow{3}{*}{ Dicamba } & Domestic & 0 & 0 & 0 \\
\hline & Monitoring & 1 & (e) 0.08 & 0.08 \\
\hline & Total & 1 & (e) 0.08 & 0.08 \\
\hline \multirow{3}{*}{ Diuron } & Domestic & 0 & 0 & 0 \\
\hline & Monitoring & 1 & (e) 0.02 & 0.02 \\
\hline & Total & 1 & (e) 0.02 & 0.02 \\
\hline \multirow{3}{*}{ Flumetsulam } & Domestic & 1 & (e) 0.0068 & 0.0068 \\
\hline & Monitoring & 0 & 0 & 0 \\
\hline & Total & 1 & (e) 0.0068 & 0.0068 \\
\hline \multirow{3}{*}{ Hydroxyatrazine } & Domestic & 2 & (e) 0.011 - (e) 0.02 & 0.0155 \\
\hline & Monitoring & 9 & (e) 0.004 - (e) 0.556 & 0.007 \\
\hline & Total & 11 & (e) 0.004 - (e) 0.556 & 0.008 \\
\hline \multirow{3}{*}{ Imazaquin } & Domestic & 0 & 0 & 0 \\
\hline & Monitoring & 3 & (e) 0.025 - (e) 0.15 & 0.043 \\
\hline & Total & 3 & (e) 0.025 - (e) 0.15 & 0.043 \\
\hline \multirow{3}{*}{ MCPA } & Domestic & 0 & 0 & 0 \\
\hline & Monitoring & 1 & (e) 3.6 & 3.6 \\
\hline & Total & 1 & (e) 3.6 & 3.6 \\
\hline \multirow{3}{*}{ Metolachlor } & Domestic & 0 & 0 & 0 \\
\hline & Monitoring & 4 & $0.005-0.01$ & 0.007 \\
\hline & Total & 4 & $0.005-0.01$ & 0.007 \\
\hline \multirow{3}{*}{ Metolachlor Ethane Sulfonic Acid } & Domestic & 4 & $0.06-0.6$ & 0.12 \\
\hline & Monitoring & 8 & $0.1-2.86$ & 0.53 \\
\hline & Total & 12 & $0.06-2.86$ & 0.31 \\
\hline \multirow{3}{*}{ Metolachlor Oxanilic Acid } & Domestic & 0 & 0 & 0 \\
\hline & Monitoring & 3 & $0.25-1.71$ & 0.62 \\
\hline & Total & 3 & $0.25-1.71$ & 0.62 \\
\hline \multirow{3}{*}{ Oryzalin } & Domestic & 0 & 0 & 0 \\
\hline & Monitoring & 1 & 0.22 & 0.22 \\
\hline & Total & 1 & 0.22 & 0.22 \\
\hline \multirow{3}{*}{$\mathrm{P}, \mathrm{P}^{\prime} \mathrm{DDE}$} & Domestic & 0 & 0 & 0 \\
\hline & Monitoring & 3 & (e) $0.001-$ (e) 0.002 & 0.002 \\
\hline & Total & 3 & (e) $0.001-$ (e) 0.002 & 0.002 \\
\hline \multirow{3}{*}{ Prometon } & Domestic & 6 & (e) $0.004-0.091$ & 0.0075 \\
\hline & Monitoring & 6 & (e) $0.004-0.094$ & 0.014 \\
\hline & Total & 12 & (e) $0.004-0.094$ & 0.011 \\
\hline \multirow{3}{*}{ Simazine } & Domestic & 2 & (e) $0.001-$ (e) 0.004 & 0.0025 \\
\hline & Monitoring & 0 & 0 & 0 \\
\hline & Total & 2 & (e) $0.001-$ (e) 0.004 & 0.0025 \\
\hline \multirow{3}{*}{ Terbacil } & Domestic & 0 & 0 & 0 \\
\hline & Monitoring & 2 & (e) 0.007 - (e) 0.008 & 0.0075 \\
\hline & Total & 2 & (e) 0.007 - (e) 0.008 & 0.0075 \\
\hline \multirow{3}{*}{ Triclopyr } & Domestic & 1 & (e) 0.01 & 0.01 \\
\hline & Monitoring & 1 & (e) 1.13 & 1.13 \\
\hline & Total & 2 & (e) 0.01 - (e) 1.13 & 0.57 \\
\hline
\end{tabular}




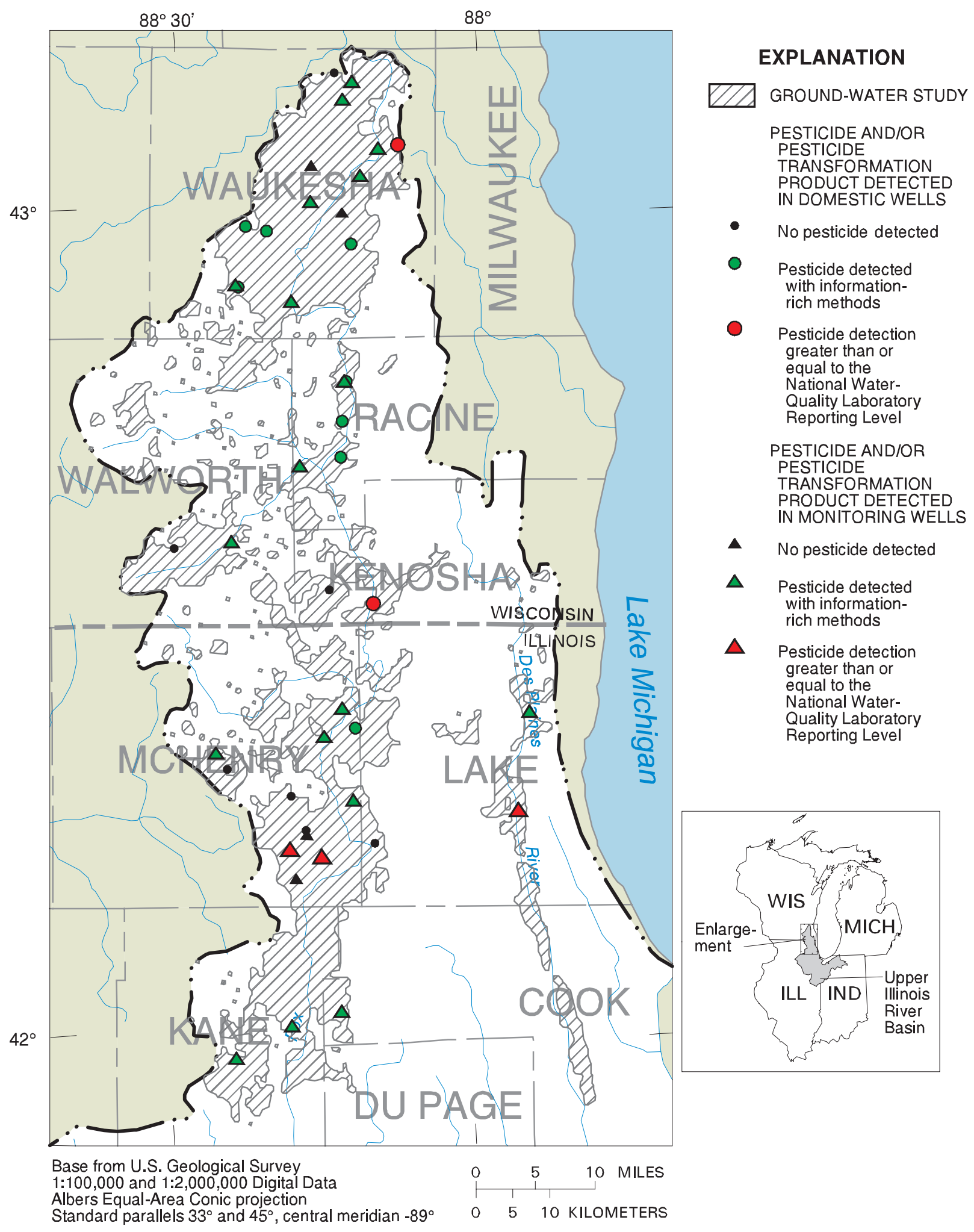

Figure 5. Pesticide and pesticide transformation product detections in wells in urbanized areas in northern Illinois/southern Wisconsin. 


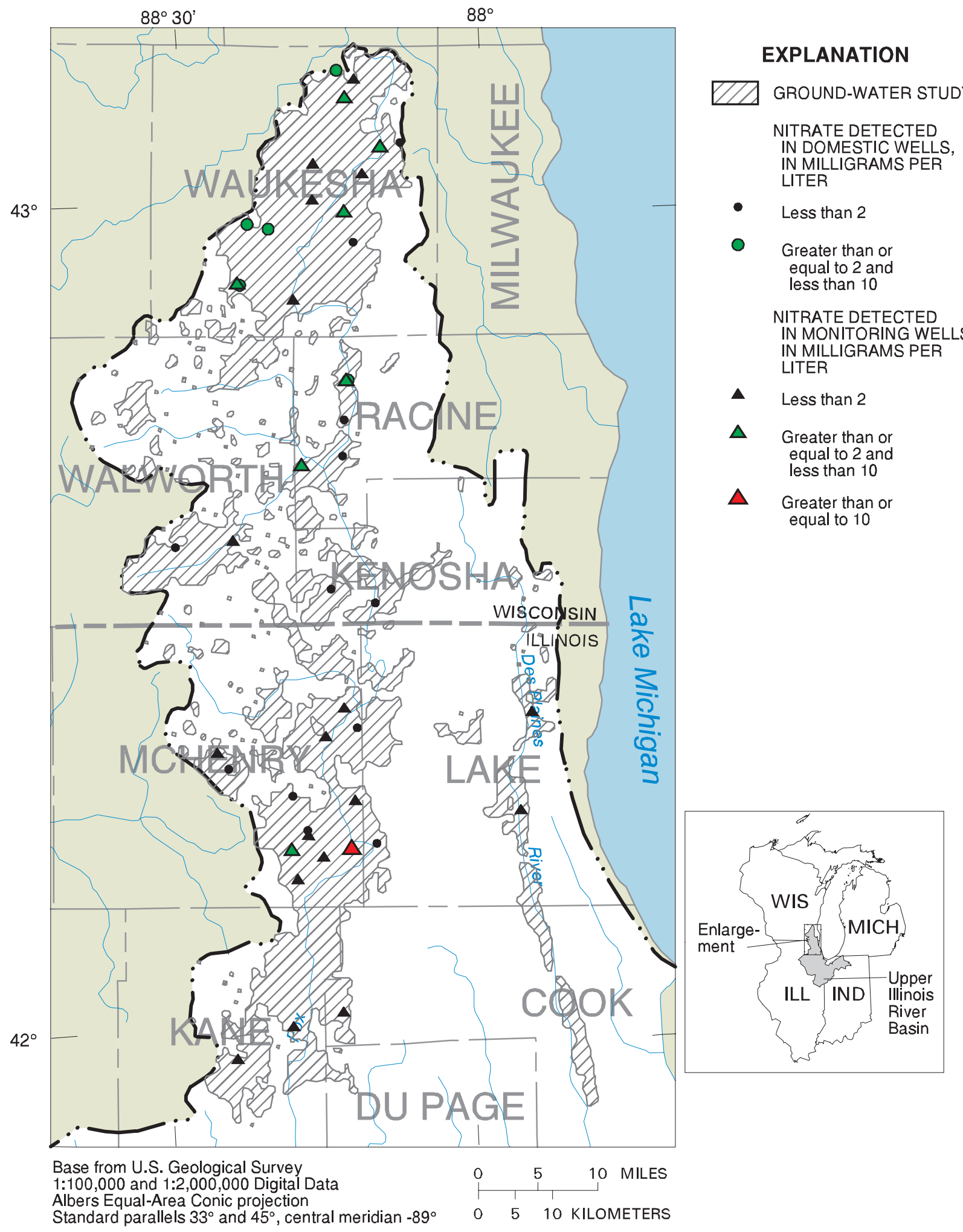

Figure 6. Nitrate detections in wells in urbanized areas in northern Illinois/southern Wisconsin. 


\section{RELATIONS AMONG ANTHROPOGENIC CONSTITUENTS WITH OTHER CHEMICAL CONSTITUENTS AND PHYSICAL CHARACTERISTICS}

\section{Volatile Organic Compounds}

Because individual VOCs were detected with insufficient frequency in this study to use in correlation tests, summed concentrations of those compounds analyzed were calculated by summing the informationrich method concentrations for each well. These summed concentrations then were used in correlations with inorganic constituents, field parameters, and well characteristics. Summed concentrations did not correlate significantly with any inorganic constituent, field parameter, or well characteristic. The correlations of summed concentrations with well depth and dissolved oxygen were less than \pm 0.10 with or without the large VOC (MTBE) outlier detection. VOC concentrations were detected in wells ranging from the shallowest to the deepest.

Chloroform, the VOC with the largest number of detections ( 9 detections from 38 samples, or 24 percent), correlated significantly with dissolved oxygen $(\mathrm{Sr}=0.49)$. This correlation may be because reductive dehalogenation of chloroform occurs more frequently in reducing conditions (Bouwer, 1994). Chloroform's significant correlations with iron $(\mathrm{Sr}=-0.52)$, more commonly found in reducing environments, and nitrate $(\mathrm{Sr}=0.47)$, more commonly found in oxidizing environments, also are indicative of chloroform's occurrence in oxidizing environments. Chloroform negatively correlated with well depth $(\mathrm{Sr}=-0.30$, $\mathrm{p}=0.07$ ); no chloroform detections were found at depths greater than $50 \mathrm{ft}$ (fig. 7).

\section{Pesticides}

The sum of all pesticide concentrations analyzed in each sample was calculated by summing the information- rich reporting level concentrations for each sample. The summed total pesticide concentrations and individual pesticides with frequent detections were used in correlations with inorganic constituents, field parameters, and well characteristics.
Summed total pesticide concentrations correlated significantly with dissolved oxygen concentrations $(\mathrm{Sr}=0.46)$ and negatively correlated significantly with well depth $(\mathrm{Sr}=-0.32)$. Similarly to summed VOC concentrations, summed total pesticide concentrations substantially decreased at well depths greater than $62 \mathrm{ft}$. Summed pesticide concentrations correlated poorly with apparent recharge date $(\mathrm{Sr}=0.24, \mathrm{p}=0.16)$, but this correlation is affected by one data point with a large pesticide concentration (MCPA)/older apparent recharge date outlier. With this outlier removed, summed pesticide concentrations correlated significantly with apparent recharge date ( $\mathrm{Sr}$ $=0.34$ ) (fig. 8).

Seven pesticides accounted for 87 of the 128 (68 percent) detections. The pesticides are atrazine, metolachlor ESA, prometon, and atrazine transformation products deethylatrazine, deethyldeisopropyl atrazine, deisopropylatrazine and hydroxyatrazine. Atrazine and its transformation products all correlated significantly with dissolved oxygen. Correlation values were atrazine $(\mathrm{Sr}=0.50)$, deethylatrazine $(\mathrm{Sr}=0.65)$, deethyldeisopropylatrazine $(\mathrm{Sr}=0.47)$, deisopropylatrazine $(\mathrm{Sr}=0.37)$, hydroxyatrazine $(\mathrm{Sr}=0.36)$, prometon $(\mathrm{Sr}=0.17$, $\mathrm{p}=0.86)$, and metolachlor ESA $(\mathrm{Sr}=0.18, \mathrm{p}=0.13)$ (fig. 9). Because atrazine degrades more readily under oxidizing conditions, the correlation of atrazine with dissolved oxygen may not be causally related, but may be more closely associated with simultaneous losses of both atrazine, and its transformation products, and dissolved oxygen as the recharge waters move downgradient (Kolpin and others, 1994).

Correlation values were weak for most pesticides; however, a decrease with depth is apparent in all pesticides (fig. 10). For example, prometon, whereas having a weak correlation with depth, shows a distinct decrease of detections with depth, with no detection occurring greater than $62 \mathrm{ft}$. Of 128 detections, only 4 (3 percent) were from samples from wells greater than $62 \mathrm{ft}$ deep. Correlations with well depths ranged from -0.15 to -.0 .41 . Correlation values were: atrazine $(\mathrm{Sr}=-0.28, \mathrm{p}=0.07)$, deethylatrazine $(\mathrm{Sr}=-0.30, \mathrm{p}=0.06)$, deethyldeisopropylatrazine $(\mathrm{Sr}=-0.21, \mathrm{p}=0.18)$, deisopropylatrazine $(\mathrm{Sr}=-0.01$, $\mathrm{p}=0.95)$, hydroxyatrazine $(\mathrm{Sr}=-0.41$, significant $)$, metolachlor ESA $(\mathrm{Sr}=-0.15, \mathrm{p}=0.34)$, and prometon $(\mathrm{Sr}=-0.15, \mathrm{p}=0.37)$. 


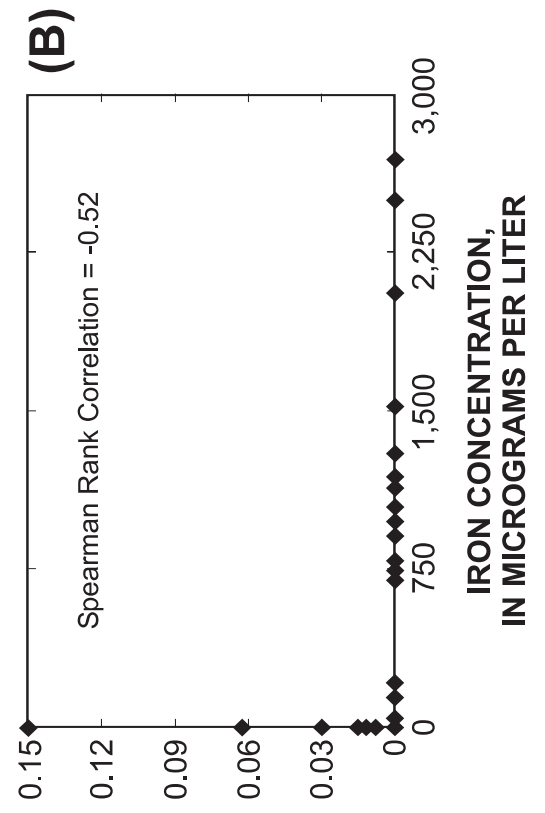

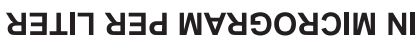

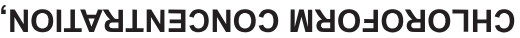

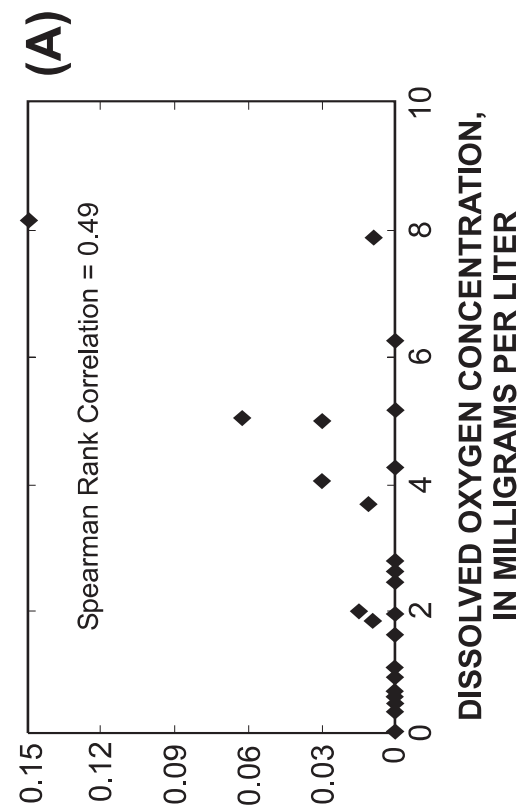

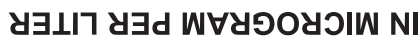

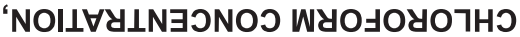

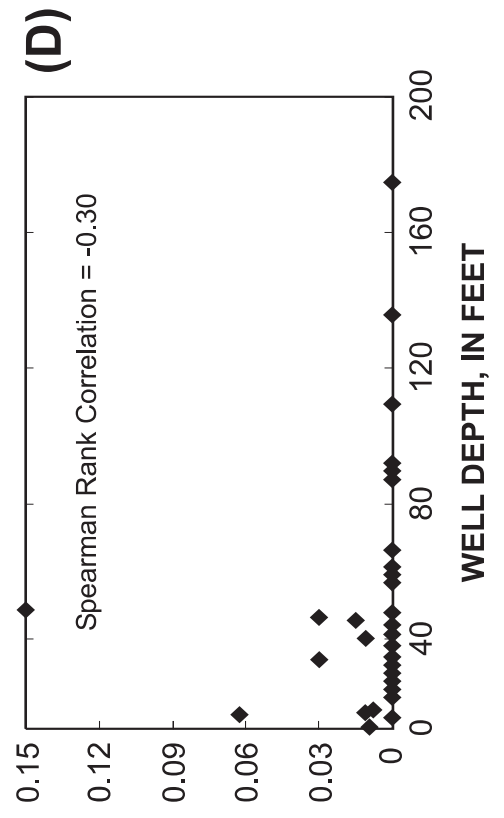

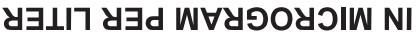

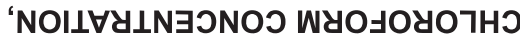

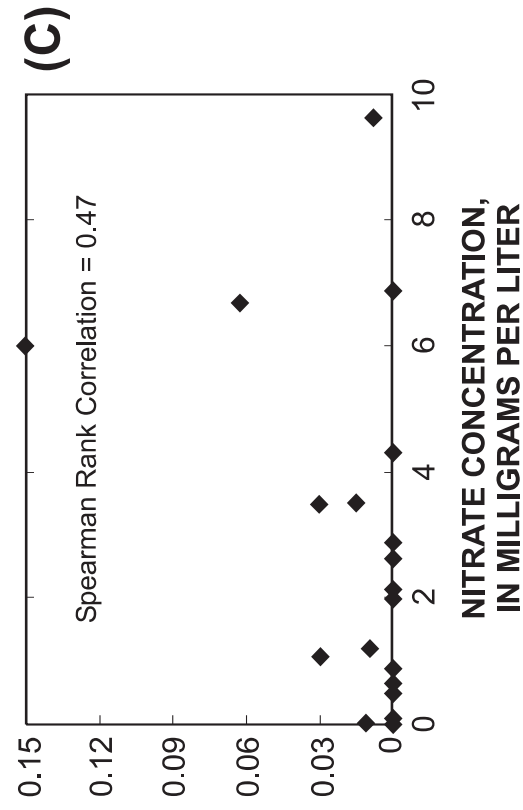

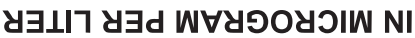

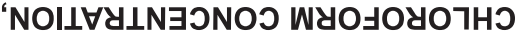

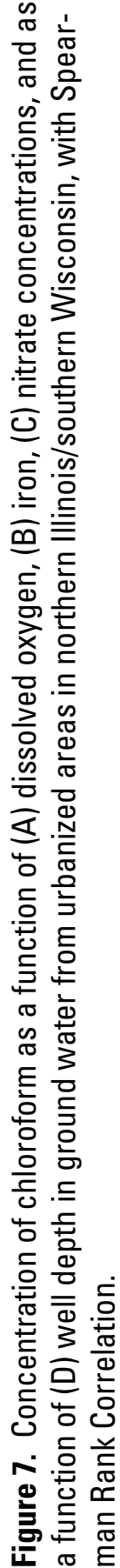


$\widehat{\underline{m}}$

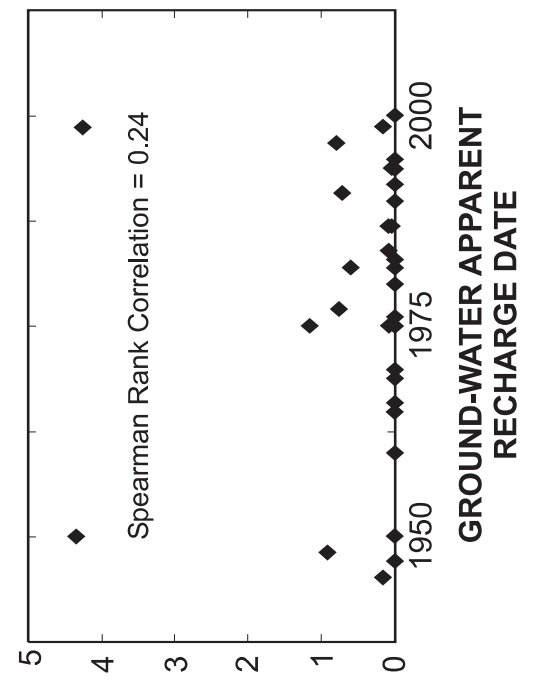

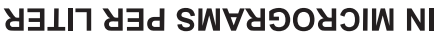

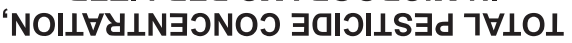

$\S$

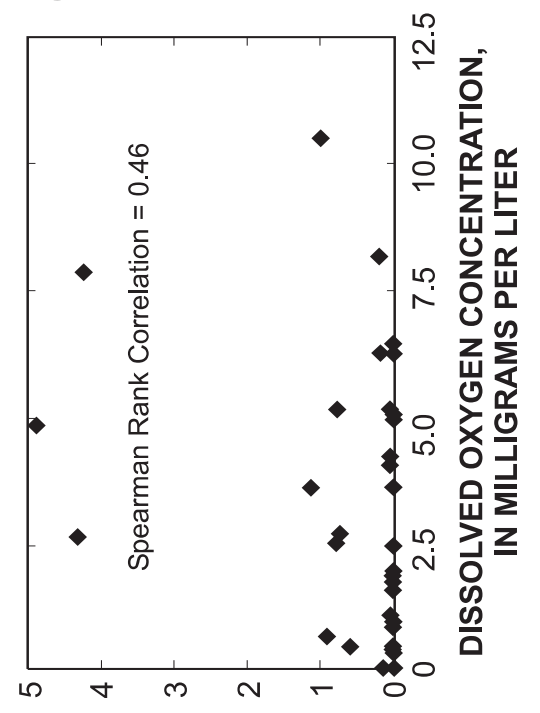

УヨコIา لy

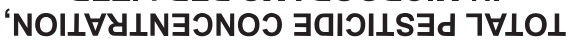

\section{อ}

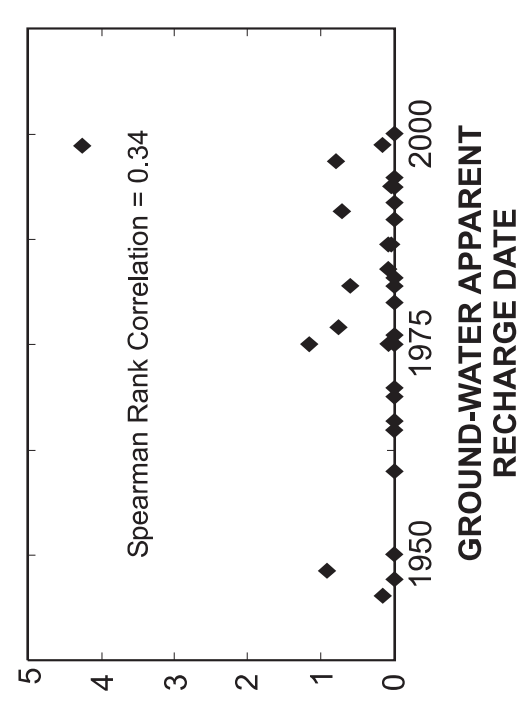

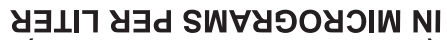

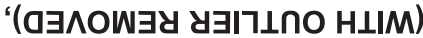

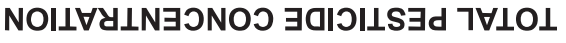

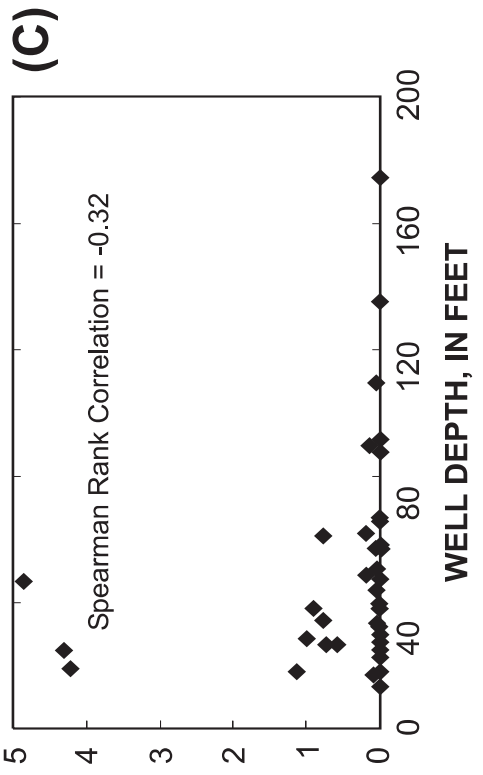

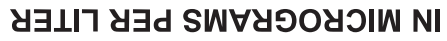

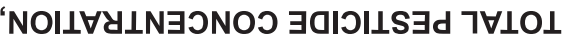

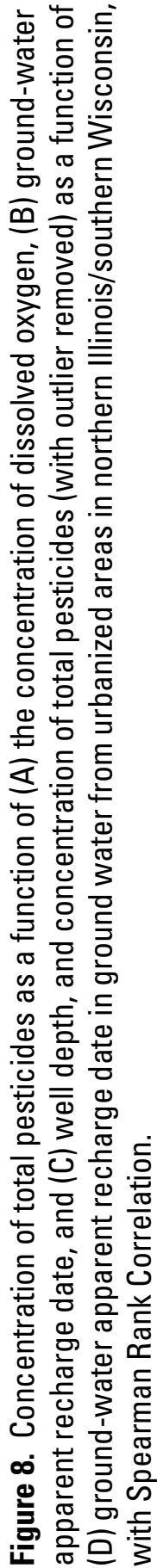



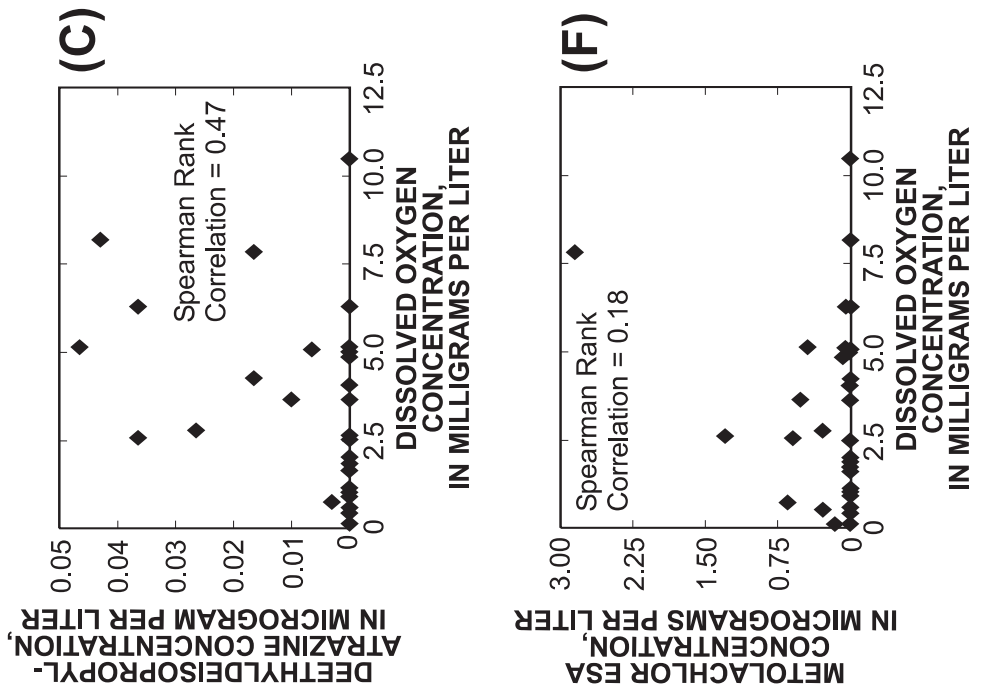

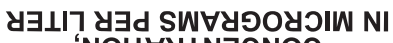 NOILYYINGONOJ \\ $\forall S \exists$ УดาHว}
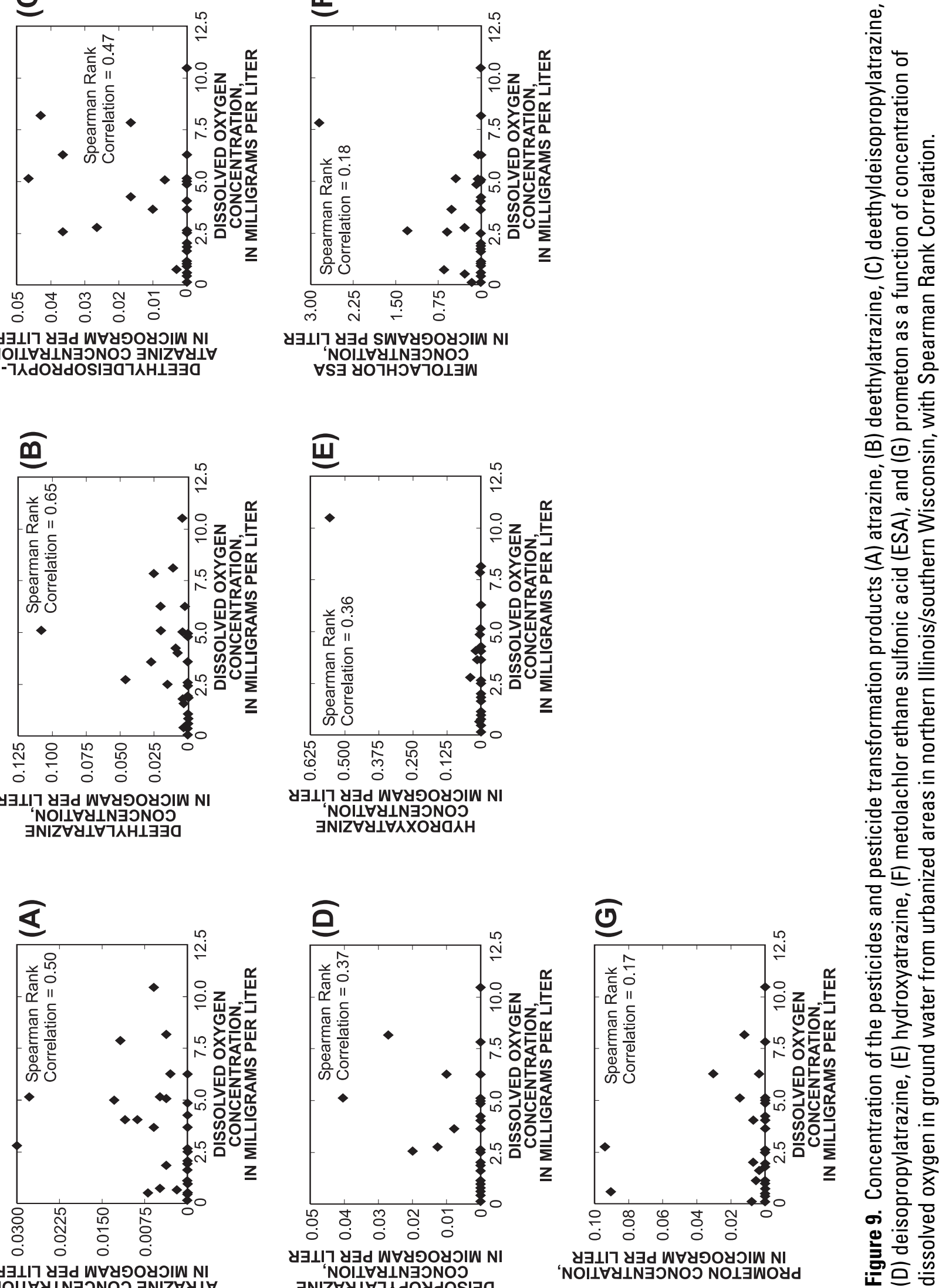

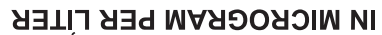 'NOII $\forall Y \perp N \exists O N O J$ $\exists N I Z \forall \forall \perp \forall า$ 새크}

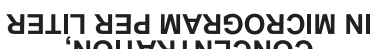

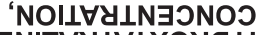

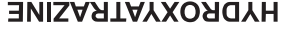

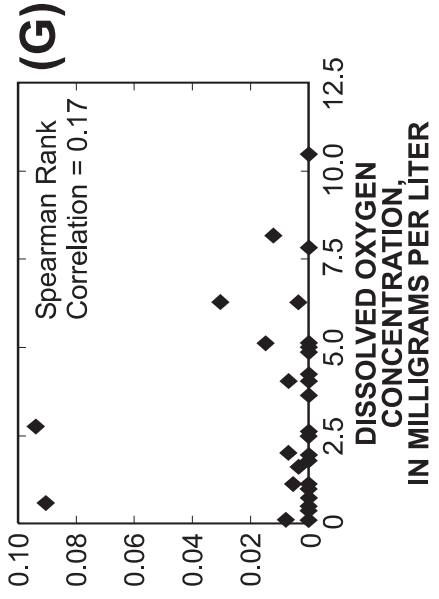

ע

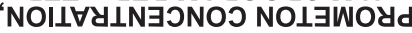

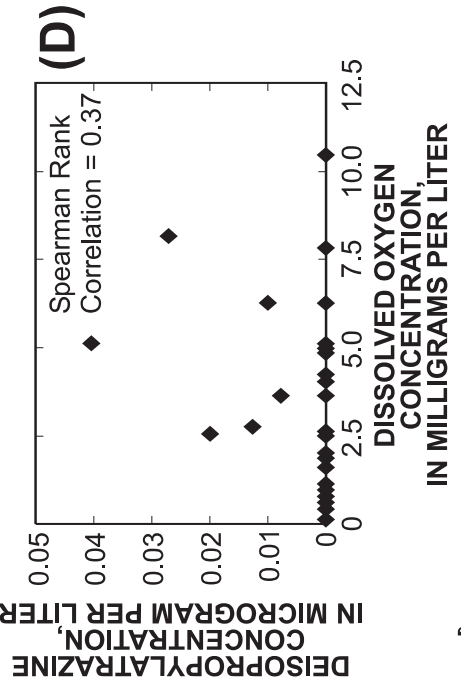

$\exists N I Z \forall Y \perp \forall 7 \wedge d O y d O S I \exists 0$ 

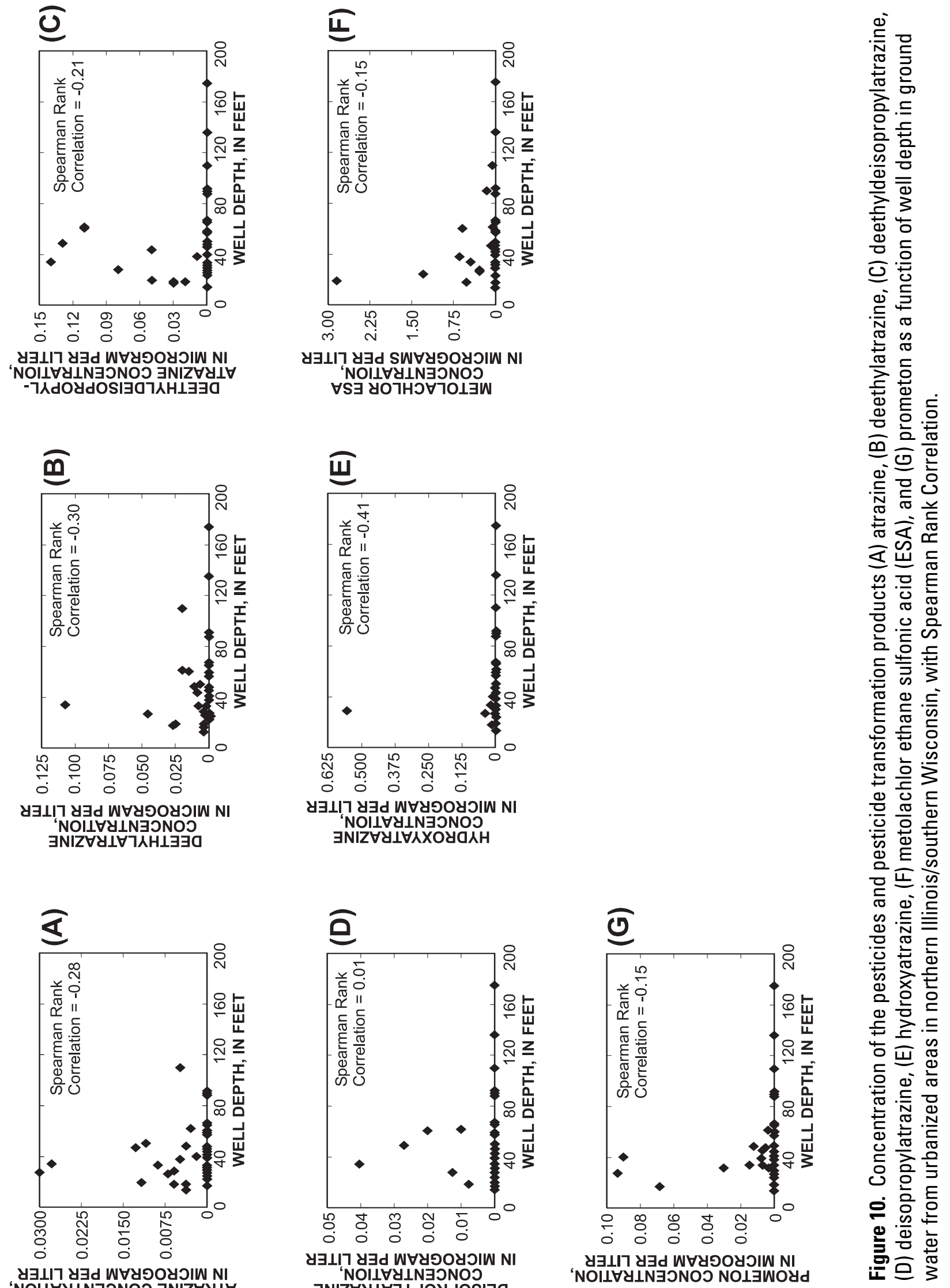

yヨ! ำ

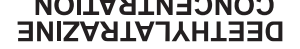
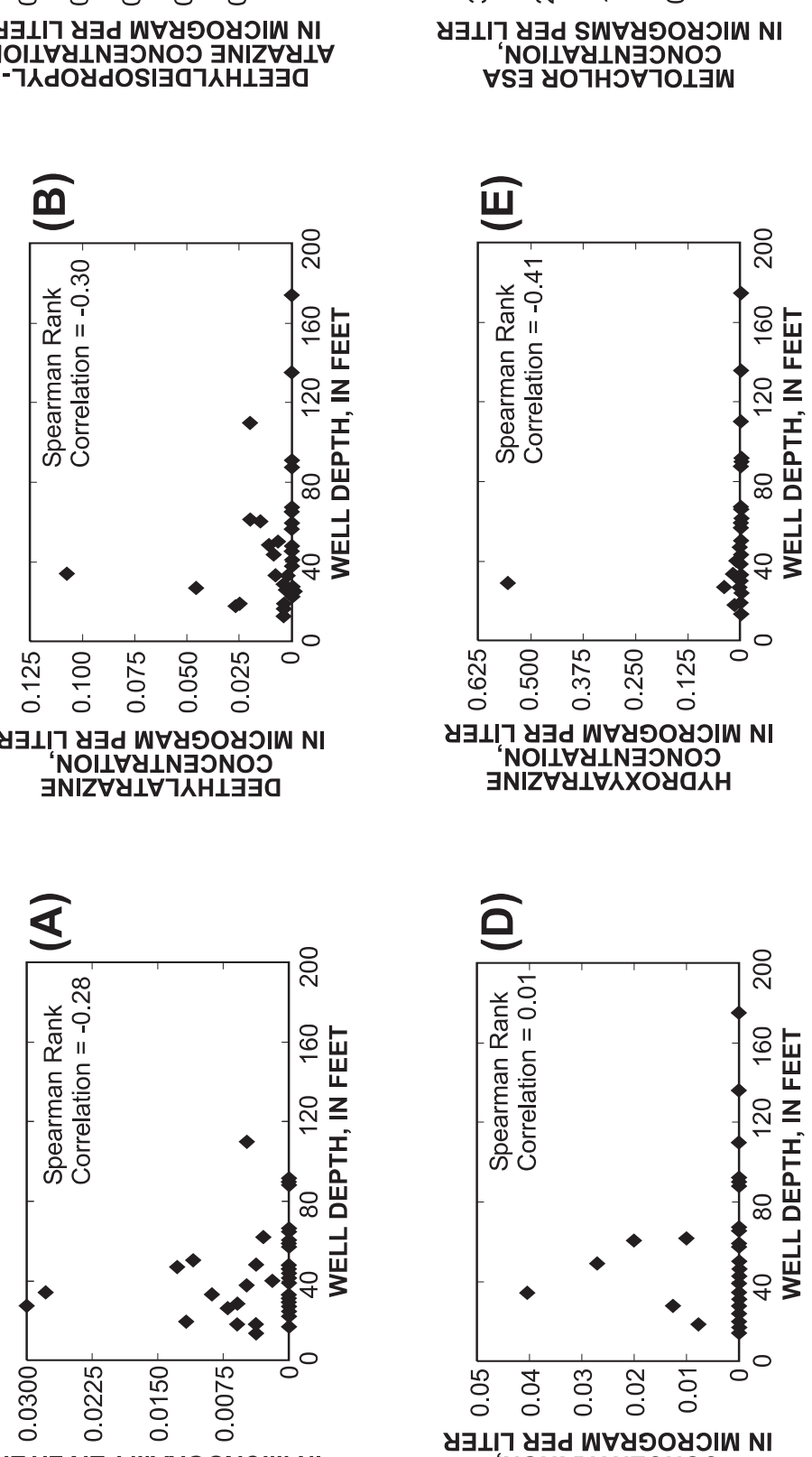

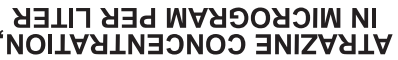

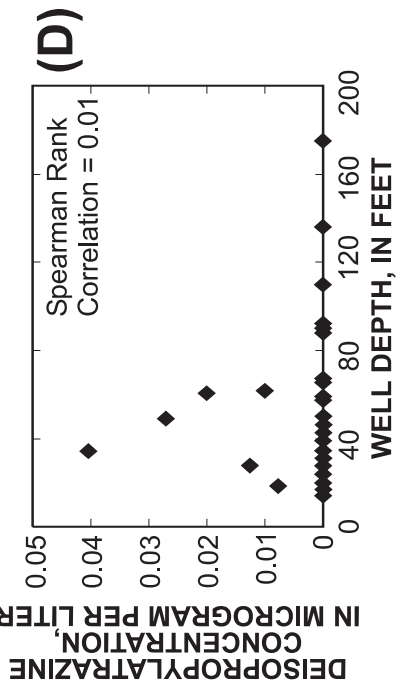

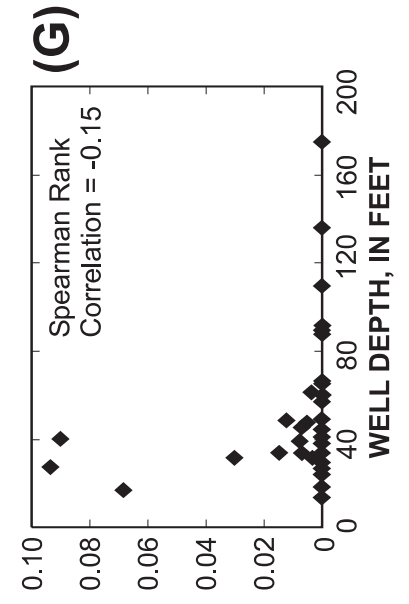

ע

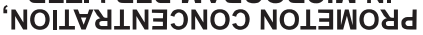


Correlation values were weak for some pesticides; however, an increase in pesticide concentration with more recent recharge dates visually is apparent in all pesticides except for metolachlor ESA (fig. 11). Of 128 detections, only 6 (5 percent) were from samples older than 1975. Metolachlor ESA accounted for three of the six detections older than 1975, although metolachlor was not commercially applied until 1977. These detections are likely an example of mixing of ground water with different ages. Correlations with apparent recharge dates ranged from -0.03 to 0.59 . Significant correlations were: atrazine $(\mathrm{Sr}=0.44)$, deethylatrazine $(\mathrm{Sr}=0.59)$, deethyldeisopropylatrazine $(\mathrm{Sr}=0.40)$, and prometon $(\mathrm{Sr}=0.34)$. Other correlations were deisopropylatrazine $(\mathrm{Sr}=0.27, \mathrm{p}=0.10)$, hydroxyatrazine $(\mathrm{Sr}=0.30, \mathrm{p}=0.08)$, and metolachlor ESA $(\mathrm{Sr}=-0.03, \mathrm{p}=0.86)$.

\section{Nitrate}

Concentrations of nitrate correlated significantly with those of dissolved oxygen $(\mathrm{Sr}=0.58)$. This correlation was expected because dissolved oxygen is an indicator of oxidizing conditions, conditions favorable for nitrate to occur, as well as of recent recharge. Nitrate is mostly absent where indicators of reduced ground-water conditions are present. Nitrate concentrations have significant negative correlations with the constituents iron $(\mathrm{Sr}=-0.66)$, nitrogen (ammonia) $(\mathrm{Sr}=-0.52)$, and arsenic $(\mathrm{Sr}=-0.52)$ (fig. 12). Occurrence of nitrate usually is accompanied by a lack of the above constituents that are present in reducing conditions.

Concentrations of nitrate also were significantly correlated with apparent recharge date $(\mathrm{Sr}=.74)$ (fig. 12). No nitrate concentrations greater than 2.0 $\mathrm{mg} / \mathrm{L}$ occur earlier than 1975 . This result may be an effect of young water from precipitation initially being oxic as it recharges the aquifer, creating an environment suitable for nitrate formation. It also is possible that the age in reducing water is skewed by anaerobic degradation of CFCs, which could decrease falsely the apparent recharge date (increase the ground-water age) in reducing conditions.
Nitrate did not correlate with depth $(\mathrm{Sr}=-0.22$, $\mathrm{p}=0.15$ ), but a decrease with depth is evident on the plot. In depths ranging from $13-175 \mathrm{ft}$, no nitrate concentrations above $2.0 \mathrm{mg} / \mathrm{L}$ were detected deeper than $66 \mathrm{ft}$ (fig. 12).

\section{SIGNIFICANCE OF RESULTS}

Using information-rich reporting levels, $37 \mathrm{VOC}$ detections occurred in 28 of 38 ( 74 percent) of the well samples. Using LRLs, VOCs were detected in 32 percent of the well samples. No VOCs exceeded USEPA drinking-water standards. Only one detection (3 percent) exceeded $1.0 \mu \mathrm{g} / \mathrm{L}$. A study of VOC occurrence in urban wells across the United States indicated that VOCs were detected in 47 percent of the well samples (Squillace and others, 1999). This national study used a censoring level of $0.20 \mu \mathrm{g} / \mathrm{L}$, higher than the $0.13 \mu \mathrm{g} / \mathrm{L}$ median detection value of VOCs at the LRLs in this report. This result indicates that VOCs may be found at a lower frequency in the upper Illinois River Basin than nationally.

Using information-rich reporting levels, 134 pesticide (or pesticide transformation product) detections occurred in 31 of 42 (74 percent) of the well samples. Using LRLs, pesticides were detected in 62 percent of the samples. No pesticides exceeded USEPA drinking-water standards. Using LRLs, only five detections (6 percent) exceeded $1.0 \mu \mathrm{g} / \mathrm{L}$. A study of pesticide occurrence in urban wells across the United States indicated that pesticides were detected in 46.6 percent of the well samples (Kolpin and others, 1998). This national study had similar LRLs, but did not include pesticide transformation products (except deethylatrazine), the majority of detections in this report.

Of the 43 wells sampled for nitrate, 1 ( 2 percent) exceeded the USEPA drinking-water standard for nitrate of $10 \mathrm{mg} / \mathrm{L}$. Of the 43 wells, 13 (30 percent) samples exceeded the national background concentration of $2 \mathrm{mg} / \mathrm{L}$ (Mueller and Helsel, 1996). A study of nutrient occurrence in shallow urban wells across the United States indicated a median nitrate concentration of $1.6 \mathrm{mg} / \mathrm{L}$ (Nolan and Stoner, 2000). This concentration was higher by an order of magnitude than the median concentration of $0.068 \mathrm{mg} / \mathrm{L}$ calculated here. 

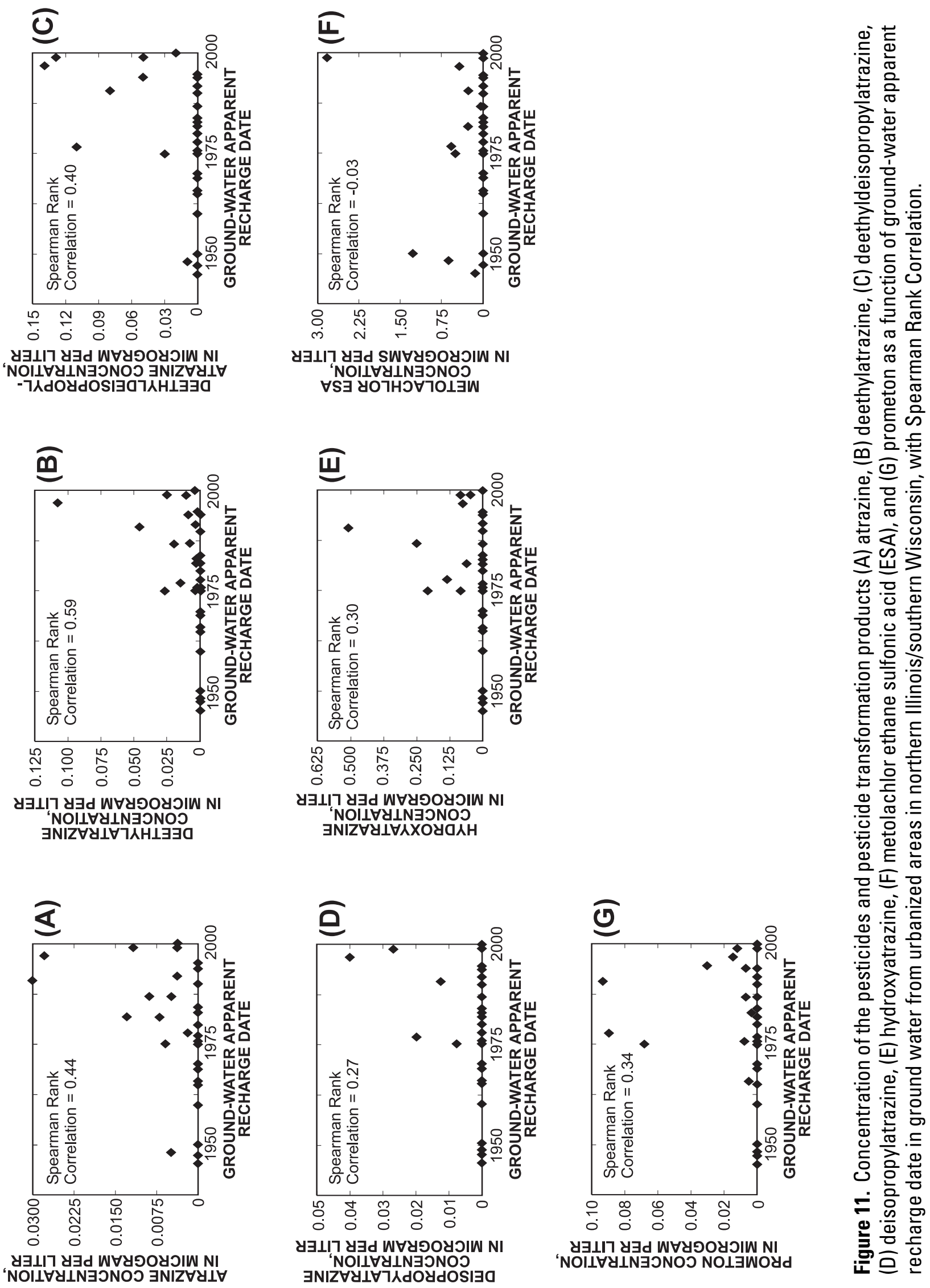


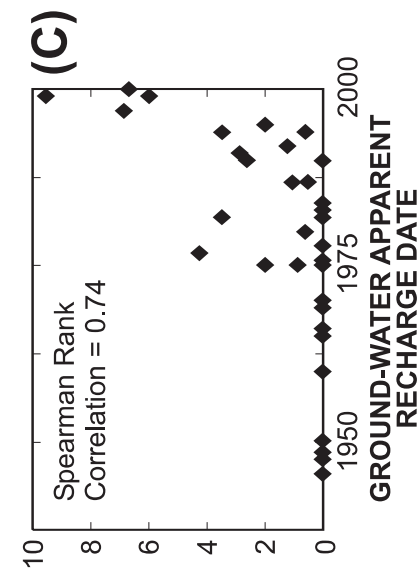

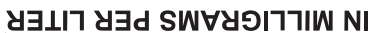
'NOIIVYIN $\exists$ ONOJ $\exists \perp \forall Y \perp I N$

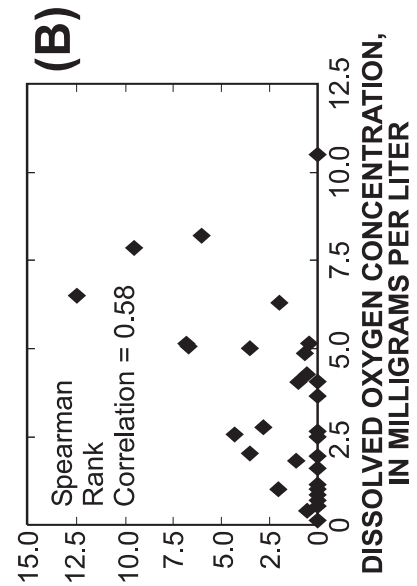

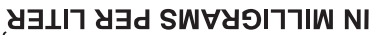

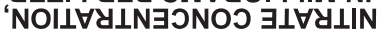

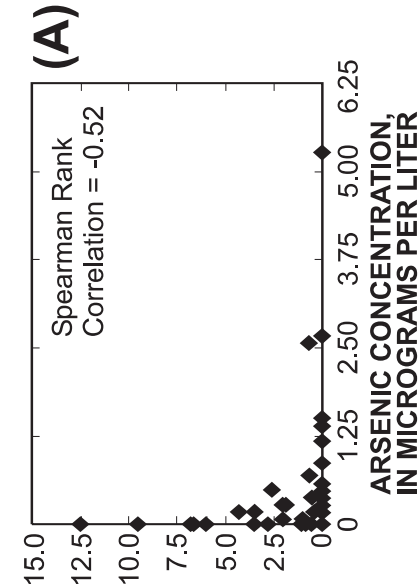

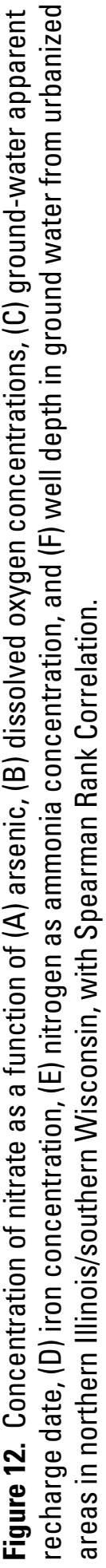
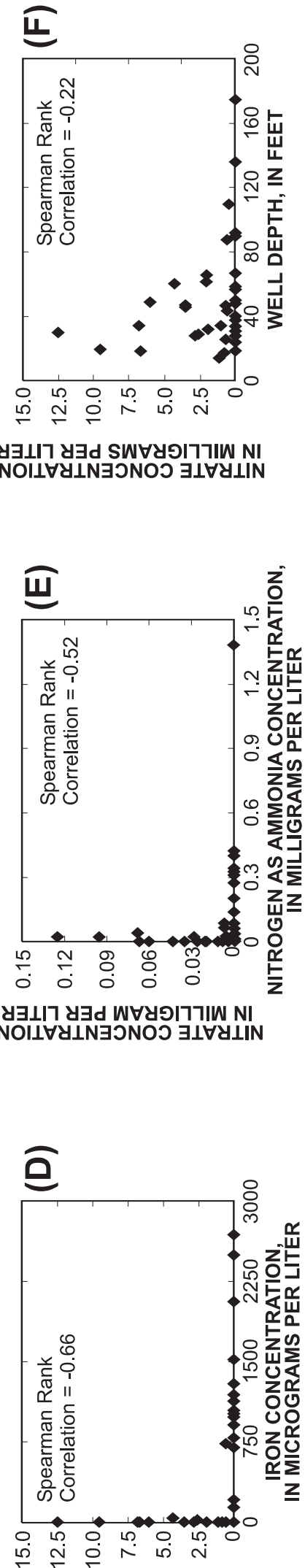

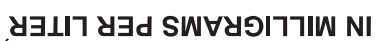

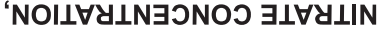

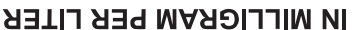

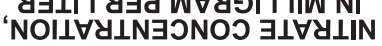

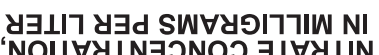


Of the 42 wells sampled for VOCs or pesticides using information-rich methods, 38 of 42 (90 percent) had at least one detection. Of the 26 wells having water samples with detections below LT-MDLs, 22 (85 percent) had at least one other VOC or pesticide detected above LRLs. If nitrate detections above $2.0 \mathrm{mg} / \mathrm{L}$ are taken into account, 40 of 43 (93 percent) had detections of a VOC or pesticide, or detections of nitrate above $2.0 \mathrm{mg} / \mathrm{L}$.

Occurrence of these constituents indicate that, although only one well sample exceeded any USEPA drinking-water standards, the majority of the wells are anthropogenically affected, but presently (2002) not at or above USEPA drinking-water regulation levels of concern. However, drinking-water standards have not been established for a number of these constituents, notably the pesticide transformation products. Pesticide transformation products frequently occur in samples with other pesticide transformation products, resulting in a mixture of multiple transformation products. Few health-risk studies have been completed concerning the effects of these mixtures.

\section{SUMMARY}

The upper Illinois River Basin is one of more than 40 study units throughout the United States where water-quality data are being collected by the U.S. Geological Survey National Water-Quality Assessment program to assess ground- and surface-water quality at a regional and national level. Increasing urbanization throughout the United States has made the occurrence and distribution of anthropogenic (caused by humans) constituents, such as volatile organic compounds (VOCs) and pesticides, in ground water a concern.

The rapidly expanding growth in the Chicago, Ill. and Milwaukee, Wis. metropolitan areas in the upper Illinois River Basin may affect the ground-water resources of these areas.

VOCs, pesticides (and their pesticide transformation products), nitrate and other chemical constituents and physical characteristics were sampled in the ground water in Quaternary glacial till deposits overlying a bedrock aquifer in the recently urbanized areas in northeastern Illinois and southeastern Wisconsin. A total of 43 wells were sampled: 26 monitoring wells installed specifically for the study, and 17 private domestic-supply wells.
Two levels of reporting detections were used in this report. The laboratory reporting level (LRL), in which the risk of a false positive or false negative detection is less than or equal to 1 percent (percent), was used for quantitative interpretations. The semiquantitative, information-rich method level, in which estimated concentrations are identified positively and are qualified to be present based on quality-control criteria, but have an increased risk of false positive detections was used for qualitative interpretations, and general semi-quantitative interpretations and correlation statistics.

Using LRLs, VOCs were detected in 12 of 38 (32 percent) of the wells. Of the 15 detections of 7 VOCs, concentrations ranged from 0.03 (estimated) to 4.6 micrograms per liter $(\mu \mathrm{g} / \mathrm{L})$, with a median concentration of $0.13 \mu \mathrm{g} / \mathrm{L}$. Methyl tert-butyl ether (MTBE) and trichloromethane (chloroform) were the most common VOCs detected based on LRLs with 4 (10 percent) detections.

Using information-rich reporting levels, VOCs were detected in 28 of 38 ( 74 percent) of the wells with 37 detections of 15 compounds. Chloroform was the most commonly detected VOC with 9 (24 percent) detections.

Because of the relative infrequency of VOC detections compared to the number of samples taken, statistical correlation analyses only were conducted with sum of analyzed VOC concentrations and chloroform. The sum of VOC concentrations did not correlate with any of the sampled inorganic and physical parameters, including well depth, apparent ground-water recharge date, or dissolved oxygen concentrations. Chloroform concentrations correlated significantly with dissolved oxygen, and negatively correlated significantly with well depths, with no chloroform detections occurring at depths greater than $50 \mathrm{ft}$.

Using LRLs, pesticides were detected in 26 of 42 (62 percent) of the wells. Of the 83 detections of 20 pesticides, concentrations ranged from 0.003 (estimated) to 3.6 (estimated) $\mu \mathrm{g} / \mathrm{L}$, with a median concentration of $0.06 \mu \mathrm{g} / \mathrm{L}$. Deethylatrazine, a transformation product of atrazine, was the most common pesticide detected using LRLs, with 18 (43 percent) detections.

Using information-rich reporting levels, pesticides were detected in 31 of 42 ( 74 percent) of the wells with 134 detections of 29 pesticides. 
Deethylatrazine was the most commonly detected pesticide using information-rich methods, with 19 (45 percent) detections. Atrazine and four atrazine transformation products accounted for 49 percent of all pesticide detections.

Summed concentrations of analyzed pesticides positively correlated with dissolved oxygen and negatively correlated with well depth. Seven pesticides accounted for 68 percent of the detections. These are the pesticides atrazine, prometon, and the pesticide transformation products deethylatrazine, deethyldeisopropyl atrazine, deisopropyl atrazine, hydroxyatrazine, and metolachlor ESA. Pesticide concentrations, except for metolachlor ESA, generally decreased with increasing well depth and decreasing apparent ground-water recharge date.

Nitrate concentrations ranged from less than 0.047 to $12.5 \mathrm{mg} / \mathrm{L}$ with a median concentration of $0.068 \mathrm{mg} / \mathrm{L}$. Of the 43 wells sampled for nitrate, 13 samples (30 percent) had nitrate concentrations exceeding the estimated national background concentration level of $2 \mathrm{mg} / \mathrm{L}$. Nitrate concentrations correlated with dissolved oxygen and apparent groundwater recharge date.

Of the 42 wells sampled for VOCs or pesticides using information-rich methods, 38 of 42 (90 percent) had at least one detection. If nitrate detections above $2.0 \mathrm{mg} / \mathrm{L}$ are taken into account, 40 of 43 (93 percent) had detections of a VOC or pesticide, or detections of nitrate above $2.0 \mathrm{mg} / \mathrm{L}$. This result indicates that most of these wells are anthropogenically affected.

No individual VOC or pesticide concentrations exceeded U.S. Environmental Protection Agency (USEPA) drinking-water standards, and only one nitrate detection exceeded the standards. The percentage of these detections indicate that most of the wells are anthropogenically affected, but presently not at or above USEPA drinking-water regulation levels of concern. Health effects of many of these compounds, particularly pesticide transformation products, and mixtures of multiple pesticide transformation products, however, have not been determined. 


\section{REFERENCES}

Arnold, T.L., Sullivan, D.J., Harris, M.A., Fitzpatrick, F.A., Scudder, B.C., Ruhl, P.M., Hanchar, D.W., Stewart, J.S., 1999, Environmental setting of the upper Illinois River Basin and implications for water quality: U.S. Geological Survey WaterResources Investigations Report 98-4268, 67 p.

Bouwer, E.J., 1994, Bioremediation of chlorinated solvents using alternate electron acceptors in Norris, R.D., Hinchee, R.E., Brown, R., McCarty, P.L., Semprini, L., Wilson, J.T., Kampbell, D.H., Reinhard, M., Bouwer, E.J., Borden, R.C., Vogel, T.M., Thomas, J.M., and Ward, C.H., Handbook of bioremediation: Ann Arbor, Lewis Publishers, p. 149-175.

Capel, P.D., Spexet, A.H., Larson, S.J., 1999, Occurrence and behavior of the herbicide prometon in the hydrologic system: Environmental Science and Technology, v. 33, p. 674-680.

Childress, C.J.O., Foreman, W.T., Connor, B.F., and Maloney, T.J., 1999, New reporting procedures based on long-term method detection levels and some considerations for interpretations of waterquality data provided by the U.S. Geological Survey National Water-Quality Laboratory: U.S. Geological Survey Open-File Report 99-193, 19 p.

Clark, I., and Fritz, P., 1997, Environmental Isotopes in Hydrogeology: Lewis Publishers, New York, $328 \mathrm{p}$.

Connor, B.F., Rose, D.L., Noriega, M.C., Murtagh, L.K., and Abney, S.R., 1998, Methods of analysis by the U.S. Geological Survey National WaterQuality Laboratory--Determination of 86 volatile organic compounds in water by gas chromatography/mass spectrometry, including detections less than reporting limits: U.S. Geological Survey Open-File Report 97-829, 78 p.

Fegeas, R.G., Claire, R.W., Guptill, S.C., Anderson, K.E., and Hallam, C.A., 1983, Land use and land cover digital data: U.S. Geological Survey Circular 895-E, $21 \mathrm{p}$.

Fenneman, N.M., 1938, Physiography of the eastern United States: New York, McGraw-Hill Book Co., $714 \mathrm{p}$.
Fishman, M.J., and Friedman, L.C., 1989, Methods for the determination of inorganic substances in water and fluvial sediments: U.S. Geological Survey Techniques of Water-Resources Investigations, book 5 , chap. A1, $545 \mathrm{p}$.

Furlong, E.T., Anderson, B.D., Werner, S.L., Soliven, P.P., Coffey, L.J., and Burkhardt, M.R., 2001, Methods of analysis by the U.S. Geological Survey National Water-Quality Laboratory--

Determination of pesticides in water by graphitized carbon-based solid-phase extraction and high-performance liquid chromatography/ mass spectrometry: U.S. Geological Survey Water-Resources Investigations Report 01-4134, $73 \mathrm{p}$.

Hitt, K.J., 1995, Refining 1970's land-use data with 1990 population data to indicate new residential development: U.S. Geological Survey WaterResources Investigations Report 94-4250, 15 p.

Kelly, W.R., and Wilson, S.D., 2002, Temporal changes in shallow groundwater quality in northeastern Illinois, in 12th Annual Research Conference: Research on Agricultural Chemicals and Groundwater Resources in Illinois, Carbondale, Ill., 2002, Proceedings: 2002 Illinois Groundwater Consortium: accessed November 8, 2002, at URL http://www.siu.edu/orda/igc/proceedings/02/ contents.html

Kolpin, D.W., Barbash, J.E., and Gilliom, R.J., 1998, Occurrence of pesticides in shallow groundwater of the United States: Initial results from the National Water-Quality Assessment Program: Environmental Science and Technology, v. 32, n. 5, p. 558-566.

Kolpin, D.W., Burkart, M.R., and Thurman, E.M., 1994, Herbicides and nitrate in near-surface aquifers in the mid-continental United States, 1991: U.S. Geological Survey Water-Supply Paper 2413, 34 p.

Koterba, M.T., Wilde, F.D., Lapham, W.W., 1995, Ground-water data-collection protocols and procedures or the National Water-Quality Assessment Program: Collection and documentation of water-quality samples and related data: U.S. Geological Survey Open-File Report 95-399, 113 p. 
Lapham, W.L., Wilde, F.D., and Koterba, M.T., 1995, Ground-water data-collection protocols and procedures for the National Water-Quality Assessment Program: Selection, installation, and documentation of wells, and collection of related data: U.S. Geological Survey Open-File Report 95-398, 69 p.

Lee, E.A., Kish, J.L., Zimmerman, L.R., and Thurman, E.M., 2001, Methods of analysis by the U.S. Geological Survey Organic Geochemistry Research Group--Update and additions to the determination of chloroacetanilide herbicide degradation compounds in water using highperformance liquid chromatography/mass spectrometry: U.S. Geological Survey Open-File Report 01-10, 17 p.

Leighton, M.M., Ekblaw, G.E., and Horberg, C.L., 1948, Physiographic divisions of Illinois: Illinois State Geological Survey Report of Investigation $129,19 \mathrm{p}$.

Mueller, D.K., and Helsel, D.R., 1996, Nutrients in the Nation's water--Too much of a good thing?: U.S. Geological Survey Circular 1136, 24 p.

Nolan, B.T., and Stoner, J.D., 2000, Nutrients in ground waters of the conterminous United States, 1992-1995: Environmental Science and Technology, v. 34, n. 7, p. 1156-1165.

Plummer, L.N., and Busenberg, E., 2000, Chlorofluorocarbons in P. Cook and A. Herczeg eds., Environmental Tracers in Subsurface Hydrology: Kluwer Academic Press, Boston, chap. 15, p. 441-478.

Plummer, L. and Friedman, L., 1999, Tracing and dating young ground water: U.S. Geological Survey Fact Sheet 134-99, 4 p.

Schlosser, P., Stute, M., Dörr, C., Sonntag, C., and Münnich, K.O., 1988, Tritium/3He-dating of shallow groundwater: Earth Planet, Sci. Lett., v. 89 , p. 353-362.

Schlosser, P., Stute, M., Sonntag, C., and Münnich, K.O., 1989, Tritiogenic 3He in shallow groundwater: Earth Planet, Sci. Lett., v. 94, p. 245-256.
Schneider, A.F., 1966, Physiography: The Indiana Sesquicentennial Volume, Natural Features of Indiana: Indiana Academy of Science, State Library, Indianapolis, Indiana, p. 40-56.

Scott, J.C., 1990, Computerized stratified random siteselection approaches for design of a ground-waterquality sampling network: U.S. Geological Survey Water-Resources Investigations Report 90-4101, $109 \mathrm{p}$.

Squillace, P.J., and Price, C.V., 1996, Urban land-use study plan for the National Water-Quality Assessment program: U.S. Geological Survey Open-File Report 96-217, 22 p.

Squillace, P.J., Moran, M.J., Lapham, W.W., Price, C.V., Clawges, R.M., and Zogorski, J.S., 1999, Volatile organic compounds in untreated ambient groundwater of the United States, 1985-1995: Environmental Science and Technology, v. 33, no. 23, p. 4176-4187.

U.S. Environmental Protection Agency, Office of Water, 2000, Drinking water standards and health advisories: U.S. Environmental Protection Agency Publication EPA 822-B-00-001, 12 p.

Vogelmann, J.E., Howard, S.M., Yang, L., Larson, C.R., Wylie, B.K., and Van Driel, N., 2001, Completion of the 1990s National land cover data set for the conterminous United States from Landsat Thematic Mapper data and ancillary data sources: Photogrammetric Engineering and Remote Sensing 67, p. 650-662.

Zaugg, S.D., Sandstrom, M.W., Smith, S.G., and Fehlberg, K.M., 1995, Methods of analysis by the U.S. Geological Survey National Water-Quality Laboratory--Determination of pesticides in water by $\mathrm{C}-18$ solid-phase extraction and capillarycolumn gas chromatography/mass spectrometry with selected-ion monitoring: U.S. Geological Survey Open-File Report 95-181, 60 p. 